\title{
Sur'un Kamulaştırılması Üzerine Kimin Ne Söylediği Verilen Bilgiye Yönelik Değerlendirmeyi ve Kolektif Suçluluğu Etkiler mi?
}

\author{
Leman Korkmaz \\ Atılım Üniversitesi
}

\author{
Dicle Rojda Tasman ${ }^{2}$ \\ Hacettepe Üniversitesi
}

\begin{abstract}
Özet
Bu araştırmada, mesajın kaynağı, mesajın odağı; etnik-Türk kimliği ile özdeşleşme ve olayın meşruiyetine ilişkin algı olmak üzere alıcıyla ilgili faktörlerin, kolektif suçluluk ve mesajın değerlendirilmesi üzerindeki etkisini incelemeyi amaçladık. Deneysel manipülasyon için Kürtlerin yoğun olarak yaşadığı Diyarbakır'ın Sur ilçesindeki kamulaştırılma sürecini ele aldık. Üç yüz kırk etnik-Türk katılımcıdan oluşan örneklemi, mesaj kaynağının fail olduğu fail odaklı anlatım, mesaj kaynağının mağdur olduğu mağdur odaklı anlatım, mesaj kaynağının fail olduğu mağdur odaklı anlatım ve mesaj kaynağının mağdur olduğu fail odaklı anlatım olmak üzere 4 koşuldan birine seçkisiz olarak atadık. Mesajın değerlendirilmesine yönelik bulgulara baktığımızda, etnik-Türk kimliği ile özdeşleşme düzeyleri yüksek katılımcıların mağdurun hem fail hem de mağdur odaklı anlatımını daha yanlı bulduğu ortaya çıkmıştır. Ayrıca, Sur'un kamulaştırılmasını meşru gören katılımc1lar, mağdurun mağdur odaklı açıklamalarını daha yanlı değerlendirmişlerdir. Diğer bir ifadeyle, bulgular Kürtlerin yoğun olarak yaşadığı bölgelerdeki mağdur kişilerden gelen bilgilerin, Türk kimliği ile özdeşleşme düzeyi yüksek ve yaşanan mağduriyetin meşru olduğunu düşünen etnik-Türk kişiler tarafından daha yanlı algılanabileceğini göstermiştir. Kolektif suçluluğa ilişkin bulgular ise, mesajla ilgili yarattı̆̆ımız koşulların anlamlı etkisine işaret etmezken, etnik-Türk kimliği ile daha yüksek düzeyde özdeşleşen ve Sur'un kamulaştırmasını meşru gören katılımcıların daha düşük düzeyde kolektif suçluluk hissettiklerini göstermiştir. Mesaja yönelik değerlendirme ve kolektif suçlulukla ilgili bulguları birlikte değerlendirdiğimizde, gruplar-arası çatı̧ma çözümüne yönelik müdahale programları ve tutum değişimi çalışmalarında mesaj kaynağı, odağı ve alıcıya ait özelliklerin birlikte değerlendirilmesinin önemli olduğu görülmektedir.
\end{abstract}

Anahtar kelimeler: Kolektif suçluluk, mesajın değerlendirilmesi, mesajın kaynağı, mesajın odağı, meşruiyet algısı, iç-grupla özdeşleşme

\begin{abstract}
In this study, we aim to investigate the effect of the source and the focus of the message, and certain characteristics of the receiver, namely ethnic Turkish identification and perceived legitimacy of the event, in predicting collective guilt and evaluation of the message. We used the expropriation process of a Kurdish region, Sur in Diyarbakır, for the experimental manipulation. We randomly assigned 340 ethnic-Turkish participants to one of the four conditions: the perpetrator's perpetrator-focused narrative, the victim's victim-focused narrative, the perpetrator's victim-focused narrative, and the victim's perpetrator-focused narrative. Results indicated that people with high Turkish identification evaluated the victims victim-focused narrative and the victims perpetrator-focused narrative as less accurate / more biased. Also, people perceiving expropriation of Sur as legitimate evaluated the victims victim-focused narrative as less accurate / more biased. In other words, when the source of the message is a victim from highly populated Kurdish regions, people with high Turkish ethnic identification and people who perceived the expropriation of Sur as legitimate evaluated the message as more biased. Considering the results on collective guilt, we found that each experimental condition has no significant effect on collective guilt. However, people with high Turkish ethnic identification and people who perceived the expropriation of Sur as legitimate scored low on collective guilt. The results on both collective guilt and message evaluation suggest that it is important to consider the effects of the source and the focus of the message, and certain characteristics of receiver simultaneously while working on attitude change strategies and intergroup conflict resolution programs.
\end{abstract}

Keywords: Collective guilt, message evaluation, source of the message, focus of the message, perceived legitimacy, ingroup identification

Yazışma Adresi: 'Öğr. Gör. Dr. Leman Korkmaz, Atılım Üniversitesi, Fen-Edebiyat Fakültesi, Psikoloji Bölümü, Kızılcaşar Mahallesi, İncek / Ankara, lemankorkmaz@yahoo.com, ORC-ID: 0000-0003-2755-7290

${ }^{2}$ Doktora öğrencisi, Hacettepe Üniversitesi, Edebiyat Fakültesi, Psikoloji Bölümü, Beytepe Kampüsü No:11, 06800 Çankaya / Ankara, dicletasman@hotmail.com, ORC-ID: 0000-0001-5569-4669

Gönderim Tarihi: 15.11 .2018

Kabul Tarihi: 05.09 .2020 


\section{Kimin Ne Söylediği Verilen Bilgiye Yönelik Değerlendirmeyi ve Kolektif Suçluluğu Etkiler mi?}

2016 y1lında, Türkiye'nin Doğu ve Güneydoğu Anadolu bölgelerinde meydana gelen çatışmalardan dolayı yıkılan kentlerinin bir kısmının yeniden inşa edileceği açıklanmıştır (Paköz ve Gün, 2016) ve riskli alan sınırları içerisinde bulunduğu öne sürülen Diyarbakır'ın Sur ilçesinin 15 mahallesi, 21 Mart 2016'da Bakanlar Kurulu kararı ile Çevre ve Şehircilik Bakanlığı tarafından acele kamulaştırma kararı ile kamulaştırılmıştır. Ayrıca ilçenin bazı mahallelerinde sokağa çıkma yasağı ilan edilmiş ve pek çok ev kamulaştırma kapsamında yık1lmıştır (Office of the United Nations the High Commissioner for Human Rights [OHCHR], 2017).

Sur'un kamulaştırılması sürecinde gazete, televizyon gibi basın yayın organları aracılığı ile konuya ilişkin pek çok farkl1 kaynaktan bölgede yaşananlarla ilgili bilgi akışı sağlanmıştır. Araştırmalara göre bir bilginin / mesajın nasıl bir etki bırakacağı, konuya ilişkin bilgiyi kimin aktardığı, verilen bilgide odaklanılan kişi / grup ya da bilgiyi alan kişiye ait bazı özelliklere göre değişiklik gösterebilmektedir (örn. Doosje, Branscombe, Spears ve Manstead, 1998). Biz de yaptığımız bu araştırmada, mesajın kaynağı, mesajın odağı ve alıcıyla ilgili faktörlerin, mesajın değerlendirilmesi ve kolektif suçluluk üzerindeki etkisini Sur bağlamında araştırmayı amaçladık. Seçtiğimiz bağlam, yani Sur'un kamulaştırılması süreci, Türk-Kürt çatışmasıyla yakından ilişkili olması nedeniyle, sunulan mesajların manipülasyonuyla, katılımcıların vereceği tepkilerde farklılık oluşturabilecek bir örnektir. Sur'un kamulaştırılmasını Türk-Kürt çatışması bağlamında ele almamızın öncelikli nedeni, Sur ilçesindeki nüfusun çoğunluğunu Kürtlerin oluşturmas1 ve bölgedeki çatışmalar ve devletin yürüttüğü güvenlik operasyonlarını takiben mahallelerin boşaltılmasıdır (Baysal, 2018, OHCHR, 2017). Ayrıca süreç hukuki açıdan (Karaaslan, 2018) ve insan hakları ihlalleri aç1sından (OHCHR, 2017) eleştirilmiş ve medyada bölge halkının evlerinden çıkmak istemediğini ve alternatif barınma imkanı bulamadıklarını belirten pek çok haber yer almıştır (örn., Ekinci, 2016; Kamer, 2017). Bu doğrultuda, biz de Türkiye'de dezavantajlı vatandaş grubu olan Kürtlerin yoğun olarak yaşadığı bölgede yaşanan bu olayla ilgili verilen bilginin kaynağı ve odağı değiştiğinde, Türkiye'deki avantajlı vatandaş grubunu oluşturan etnik-Türk bireylerin duygu ve değerlendirmelerinde ne gibi farklılıklar ortaya çıkabileceğini bu araştırma kapsamında ortaya koymayı amaçladık.

$\mathrm{Bu}$ amaç çerçevesinde, etnik-Türk katılımcılardan oluşan örnekleme, Sur'daki kamulaştırma sürecine ilişkin yapılan bir mülakata dayandığını söylediğimiz bir metin sunduk ve bu metinle mesajın kaynağını ve odağını manipüle ettik: Bazı katılımcılar mesaj kaynağını bölge halkından biri olarak, bazıları ise kamulaştırma eylemini gerçekleştiren sorumlu kişilerden biri olarak gördüler. Aynı şekilde, bazı katılımcıların okudukları metinde odak olaydan etkilenen bölge halkıyken bazılarında odak eylemi gerçekleştiren kişilerdi. Çalışmamızda, kamulaştırma sürecinden olumsuz yönde etkilendiği gerek yayınlanan raporlar gerekse gazete haberleriyle ortaya konan bölge halkını mağdur olarak; Sur'daki kamulaştırma sürecinden sorumlu kişileri de kamulaştırma eylemini gerçekleştirmeleri nedeniyle, fail olarak nitelendirdik ve mesaj kaynağı ve odağındaki değişimin mesajı okuyan Türk-etnik bireylerin mesajın içeriğine yönelik değerlendirilmelerinde ve kolektif suçluluk düzeylerindeki etkisini araştırdık. Literatürdeki bulgular olayın meşruiyetine yönelik algı ve bireyin grubuyla özdeşleșmesinin de mesajın içeriğine yönelik değerlendirmeler (örn., Doosje, Branscombe, Spears ve Manstead, 2006; Feldman, 1984) ve kolektif suçluluk düzeyi (örn., Bahns ve Branscombe, 2011; Miron, Branscombe ve Biernat, 2010) üzerinde belirleyici olabileceğini gösterdiği için bu değişkenleri de araştırmamız kapsamında inceledik.

\section{Mesaja İlişkin Değerlendirme}

Tutum ve tutum değişimine odaklanan pek çok çalışma bir mesajın değerlendirilmesinde belirleyici olan faktörleri ortaya koymaya çalışmıştır. Farklı çalışmalar mesajın kaynağı (örn., Rasinski ve Czopp, 2010), ve mesajın odağının (örn., Priester ve Petty, 1995) mesajın içeriğine yönelik değerlendirmeler üzerinde etkili değişkenler olduğunu göstermiştir. Tutum ve tutum değişimine odaklanan ve "Kim, kime, neyi, nasıl söylüyor" şeklinde de ifade edilen Mesaj Öğrenme ya da Yale Yaklaşımı da (Hovland, Janis ve Kelly, 1953) bir mesajın nasıl değerlendirileceği ya da ne derede ikna edici alg1lanacağı üzerinde durur. Yale Yaklaşımına göre mesajın ikna ediciliği, mesajı kimin verdiğine, mesajın içeriğine, hangi yolla mesajın iletildiğine ve alıcının kim olduğuna yani mesajın kime söylendiğine bağlıdır.

Mesajın kaynağı. Hovland'a (1954) göre mesajı verenin yani iletişim kaynağının konuyla ilgili uzmanlığı ve ne derece güvenilir algılandığı, alıcının mesajın içeriğini ne düzeyde kabul edeceği üzerinde belirleyicidir. Hovland, mesaj uzman bir kişiden geliyorsa kişilerin mesajın içeriğine daha yüksek oranda katıldıklarını ve mesaj kaynağının, dinleyicileri ikna ederek kazanç sağlayacağı düşünülürse, mesaj kaynağının inanılırlığının ve bununla ilişkili olarak da mesaj kaynağının ikna ediciliğinin düşeceğini belirtmiştir. Ancak Hovland kuramında mesaj kaynağının ve alıcının grup kimliklerinin önemi üzerinde durmamıştır.

Daha sonraki araştırmalar mesajın dış-grup üyesindense iç-grup üyesi tarafindan sunuluyor olmasının daha 
yüksek oranda tutum değişimine neden olduğunu göstermiştir (Mackie, Gastardo-Conaco ve Skelly, 1992). Doosje ve ark.'nın (2006) çalışmasında, araştırmacılar, Hollandalı katılımcıların dış-gruptan (Amerikalı tarihçiler) gelen bilgiyi iç-gruptan (Hollandalı tarihçiler) gelen bilgiye kıyasla daha az güvenilir değerlendirdikleri sonucuna ulaşmıştır. Bir başka çalışmada, Beyaz katılımcılara iki kişinin tartıştığ sadece Siyahi diye burs verilmesinin adaletli olmadiğı" yorumunu yaptığ bir video izletilmiştir. Bu yorumu yapan kişinin önyargılı ifadesine, Beyaz ya da Siyahi diğer konuşmacı karşı çıkmıştır (Rasinski ve Czopp, 2010). Aynı argümanları sunsalar da önyargılı ifadeye karşı ç1kan kişi Beyazsa, katılımcılar bu kişiyi daha ikna edici bulmuşlar ve daha yüksek oranda fikirlerine katıldıklarını rapor etmişlerdir. Bu çalıșmada elde edilen sonuç, daha sonra yürütülen çalışmaların da gösterdiği gibi Siyahi bireyin söylediklerinin şikayet olarak görülmesiyle de (Gulker, Mark ve Monteith, 2013) ilişkilendirilebilir.

Littleford ve Jones'un (2017) yürüttüğü bir başka çalışmada ise, Beyaz öğrencilere, Siyahi ya da Beyaz profesör tarafından ırka dayalı eşitsizlikle ilgili bilgi sunulmuştur; bulgular Siyahi profesörün Beyaz profesöre kıyasla daha sıcak / zeki, öğrencilerin konuyla ilgili bilgi alması konusunda daha yardımsever ve daha uzman algılandığını göstermiştir. Ancak, tüm olumlu değerlendirmelere karşın, Siyahi profesör aynı zamanda daha önyargılı algılanmıştır. Özetlemek gerekirse, literatürdeki bulgular, kişinin dış-grup ya da dezavantajlı grubun bir üyesi olması durumunda ya da savunduğu görüş çerçevesinde bir çıkarı olması durumunda daha yanlı algılanacağını ve öne sürdüğü görüşün daha düşük düzeyde kabul edileceğini göstermektedir.

Mesajın odağı. Mesajın odağının mesajla ilişkili değerlendirmeler üzerindeki etkisine doğrudan odaklanan çok fazla çalışma olmasa da literatürdeki bulgular, mesajın odağının mesajın değerlendirilmesinde belirleyici olabileceğine işaret etmektedir. Örneğin, yapılan çalışmalar, avantajlı grubun "avantajlarına" odaklanılan durumda, avantajlı grup üyelerinin kendi avantajlı pozisyonlarına zarar vereceği düşünülen politikaları desteklemeye daha istekli olduklarını fakat dezavantajlı grubun "dezavantajlarına" odaklanılan koşulda dezavantajlı grubun olanaklarını artıracağı düşünülen politikaları daha çok desteklediklerini göstermiştir (Lowery, Chow, Knowles ve Unzueta, 2012). Diğer bir ifadeyle, mesajın odağını değiştirdiğimizde, var olan eşitsizliğe yönelik önerilen politikanın ne derece destekleneceği de değişecektir.

Mesajda odak, bazı çalışmalarda yukarıdaki örnekte olduğu gibi, dezavantajlı ve avantajlı gruplar gibi fark1 gruplara odaklı bilgi verilmesiyle manipüle edilirken, bazı durumlarda, aktif ve pasif cümle kullanımı ile eylemi gerçekleştiren ve eylemden etkilenen kişi ya da gruba odaklı anlatım çerçevesinde incelenmektedir. Penelope (1990) aktif cümle formunun eylemi gerçekleştiren aktörü ön plana çıkararak aktöre sorumluluk yüklediğini, pasif cümle formunun ise mağduru ön plana çıkararak mağdura sorumluluk yüklediğini söylemiştir. Henley, Miller ve Beazley (1995) de yaptıkları çalışmada, cinsel şiddet içeren eylemin anlatımında pasif cümle kullanımının, diğer bir ifadeyle faili değil mağduru ön plana çıkarmanın, faile daha az sorumluluk yüklenmesine ve cinsel şiddetin daha yüksek düzeyde kabulüne neden olduğunu göstermiştir.

Mesajın odağının yaratacağı etkinin mesajın kimin tarafından sunulduğuna göre de değişmesi beklenebilir. Her ne kadar, mesajın içeriğine ve mesajın kaynağına yönelik değerlendirmeyi doğrudan ölçmemiş olsa da Littleford ve Jones'un (2017) Beyaz katılımcilarla yürüttüğü çalışmanın bulguları, Beyaz profesörün Beyazların ayrıcalıklı pozisyonunu vurgulayan konuşması koşulunda katılımcıların ırka dayalı eşitsizliği daha yüksek oranda kabul ettiklerini göstermiştir. Bu çalışmayla paralel olarak Priester ve Petty (1995) ve Petty, Fleming, Priester ve Feinstein'ın (2001) yürüttüğü çalışmalar, kaynağın kendisinden beklenmeyen, kendi çıkarlarına ters düşebilecek bir görüş ortaya attığı durumlarda (örn., çevreci açıklamalar yaparak oy toplamaya çalışması beklenen politikacının tersi yönde açıklamalarda bulunması) mesaj kaynağının daha güvenilir algılandığını göstermiştir. Diğer bir ifadeyle kaynak kendisinden beklenen ve kendisine kazanç sağlayabilecek bir görüş ortaya koyduğunda, alıcı mesaj kaynağının gerçekten bu görüşü savunduğu için mi yoksa kazanç sağlayacağı için mi bu mesajı verdiğinden emin olamaz ve bu nedenle mesajın güvenilirliği konusunda şüphe duyar ancak mesaj kaynağ1 kendi bireysel çıkarlarına ters düşecek bir görüş ortaya attığında daha güvenilir algılanır. Bu noktada bireysel ve grup çıkarlarına ters düşecek mesajların etkisinin nasıl farklılaştığı üzerinde durmak gerekir. Örneğin kişinin kendi çıkarı değil de grubunun çıkarı söz konusu ise, mesaj kaynağının grubun çıkarlarına ters düşecek bir görüş ortaya koyması, bu görüşü katılımcılar için şaşırtıcı kı1sa da mesaj kaynağının daha güvenilir algılanmasına neden olmamıştır (Petty ve ark., 2001). Araştırmacılar bu bulguyu, mesaj kaynağı grubun çıkarlarına ters düşecek bir açıklama yaptığında, alıcının kişinin bu açıklamayı yapma motivasyona yönelik yapacağı atıftaki belirsizliğe bağlamıştır (örn., kişinin bu açıklamadan bireysel bir çıkarı olabilir mi?) ve alıcının bu koşulda gelen bilgiyi işlemek için daha çok çaba harcadığını görgül bir çalışmayla göstermiştir. Tüm bu bulgular, alıcının, mesaj kaynağını ve mesajın içeriğini dikkate alarak, mesaj kaynağının bu mesajı verme motivasyonunu sorguladığını ve alıcının bu niyete yönelik yaptığı atfın, mesajın değerlendirilmesi üzerinde etkili olduğunu göstermektedir. 
Biz de yürüttüğümüz bu çalışmada, aktif ve pasif cümle kullanımı ile mağdur ve fail odaklı metinlerin katılımcılar üzerinde farklılaşan etkilerini çatışmalı gruplar bağlamında ortaya koymayı amaçladık. Fail odaklı anlatımın, mağdur odaklı anlatıma kıyasla, eylemi gerçekleştirene daha çok sorumluluk yüklenmesine neden olduğu göz önünde bulundurarak dört ayrı koşulun olası etkilerini inceledik. Mesaj kaynağı ve mesaj odağını birlikte ele aldığımız bu çalışmada, birinci koşulda failin fail odaklı anlatımı failin yaptığı eylemin sorumluluğunu almasıyla ya da yapılan eylemin meşruiyetine inanarak kendisi ya da grubu adına çıkar sağlamaya çalışmasıyla ilişkilendirilebilir. İkinci koşulda failin mağdur odaklı anlatımının failin konuyla ilgili sorumluluk yüklenmemesiyle ilişkili olması beklenebilir. Üçüncü koşulda ise mağdurun fail odaklı anlatımı mağdurun olayın sorumluluğunu faile yüklemesiyle ve son koşulda mağdurun mağdur odaklı anlatımı mağdurun eylemi gerçekleştirenlere sorumluluk yüklemeden sadece olaya ilişkin bilgi vermesiyle ilişkilendirilebilir. Sorumluluk atfı açısından belirleyici olabilecek bu koşulların nasıl bir etki bırakacağını değerlendirirken dikkate almamız gereken önemli diğer nokta ise alıcıya ait özellikler olacaktır.

Alıcının özellikleri. Mesaj Öğrenme Yaklaşımını temsil eden "Kim, kime, neyi, nasıl söylüyor" (Hovland ve ark., 1953) sorusu çerçevesinde "hangi mesajın kimden kime" gittiği mesajın nasıl bir etki bırakacağı üzerinde belirleyicidir. Literatürde bu konuya ilişkin yürütülen çalışmalara baktığımızda, mesajın kimden kime gittiğine yani mesaj kaynağı ve alıcıya odaklanan çalışmalarda incelenen önemli konulardan birinin, mesaj kaynağı ve al1c1 arasındaki benzerlik olduğunu görürüz. Mesaj kaynağ1 ve alıcı arasındaki benzerlik ise genellikle yaş, cinsiyet, etnik kimlik, doğum yeri gibi değişkenler açısından tarif edilmiştir (Feldman, 1984). Örneğin bir çalışmada, Siyahi Amerikalılardan oluşan bir örneklemde katılımcılara AIDS ile ilgili eğitici bir video izletilmiştir. Katılımc1ların Siyahi Amerikalı birinin rol aldığ videoyu Beyaz birinin rol aldığı videoya kıyasla daha güvenilir değerlendirdikleri görülmüştür (Herek ve ark., 1998).

Mesaj kaynağı ve alıcı arasındaki benzerlik belirli bir grup kimliği üzerinden değerlendirildiğinden, bu grup kimliğiyle özdeşleşme düzeyinin de mesajın değerlendirilmesi üzerinde etkili olacağı açıktır. Yukarıda bahsettiğimiz Doosje ve ark.'nın (2006) çalışmasındaki bir başka bulguya göre, iç-grup kimliğini tehdit edebilecek Hollanda'nın Endonezya'yı kolonileştirilmesiyle ilgili olumsuz bilgi farklı bir grup üyesinden, diğer bir ifadeyle Amerikalı tarihçilerden, geldiğinde Hollandalı kimliği ile özdeşleşme arttıkça bilginin daha az güvenilir değerlendirildiği görülmüştür. Bilgi bir Hollandalıdan geldiğindeyse iç-grup kimliğiyle özdeşleşme belirleyici bir değişken olarak bulunmamıştır. Bu bulgu, özellikle dış-grup üyesinden gelen bilgilerin değerlendirilmesinde iç-grupla özdeşleşme düzeyinin belirleyici olabileceğine işaret etmektedir.

Yukarıdaki bulgular dikkate alındığında Sur'un kamulaştırmasına odaklandığımız bu çalışmada, fail ve mağdurun etnik kimlikleri açıkça belirtilmediği için katılımcılar için iç-grup ve dış-grup kategorilerinin etnik kimlik üzerinden belirsiz olduğu ve bunun da hipotezlerin oluşturulması ve sonuçlarının yorumlanması açısından bir sınırlılık oluşturacağı düşünülebilir. Ancak, basın yayın organları ya da sosyal medya üzerinden maruz kaldığımız mesajlarda genellikle mesaj kaynağının etnik kimliğiyle ilgili bilginin açık olarak sunulmaması bulguların genellenebilirliği açısından bir avantajdır. Belirtildiği gibi Feldman (1984) mesaj kaynağı ve alıcı arasındaki benzerliğin genellikle yaş, cinsiyet, etnik kimlik, doğum yeri gibi değişkenler açısından tarif edildiğini söyler. $\mathrm{Bu}$ bağlamda, çalışmamızda mesaj kaynağının etnik kimliği açık olarak belirtilmese de Türk kimliğiyle özdeşleşen katılımcıların, çoğunluğunu Türklerin oluşturduğu Türkiye Cumhuriyeti Devleti tarafindan görevlendirilen Sur'un kamulaştırmasından sorumlu kişiyi kendilerine daha benzer algılayarak iç-grup üyesi olarak değerlendirmeleri; insan hakları ihlalleriyle gündeme gelen Kürtlerin yoğun olarak yaşadığı Sur bölgesinde yaşayan ve evi kamulaştırılan kişiyi diş-grup üyesi olarak kategorilendirmesi muhtemeldir. Yine benzer bir biçimde, Çoymak'ın (2020) çalışması Türkiye'nin Doğu illeri düşünüldüğünde ya da Doğulu kişilerden bahsedildiğinde bir sosyal temsil olarak Türklerin bu kişileri değerlendirirken Kürt etnik grubuna yönelik bilişsel şemalarının aktive olduğunu ve akla Kürt vatandaş grubunun geldiğini göstermektedir. Bu nedenle, bizim çalışmamızda da Türk kimliğiyle özdeşleşme düzeyi düşük katılımcılara kıyasla, Türk kimliğiyle özdeşleşme düzeyi yüksek katılımcıların, dezavantajlı grup üyesi olan mağdur bireyin hem fail hem de mağdur odaklı açıklamalarını daha yanlı değerlendirmesi beklenmektedir.

Sherif ve Hovland (1961) yeni gelen bir mesaj1 değerlendirirken, kişilerin o konu hakkında daha önce var olan görüşleri çerçevesinde bir değerlendirme yaptıklarını söyler. Eğer, yeni gelen mesaj kişinin önceden sahip olduğu görüşe yakınsa kişinin bu mesajı kabul etme olasılığ daha fazla olacaktır. Bu da bizim çalışmamızda, mesajın kaynağı ve odağını manipüle ettiğimiz koşulların, mesajın değerlendirilmesi üzerinde nasıl bir etki bırakacağında iç-grupla özdeşleşme değişkeni gibi, kişilerin olayın meşruiyetine yönelik algılarının da belirleyici olabileceğine işaret eder. Bu önermeyle tutarlı olarak, mesajın odağı ile ilgili olan ve aktif-pasif cümle kullanımının etkisine odaklanan bazı araştırmacılar, pasif cümle formunun mesajın yorumlanmasında belirsizlik yarattığını ve alıcının önceki tutumlarına bağlı olarak ya- 
pilan yorumunun değişebileceğini dile getirmiștir (örn., Bohner, 2001). Bohner'in (1998, akt., Bohner, 2001) yürüttügüu çalışmada, tecavüzlerle ilgili mitlere inananların, diğer bir ifadeyle tecavüzü meşrulaştıranların, pasif cümle kullanıldığında mağdura yönelik daha olumsuz değerlendirmeler yaparken, bu mitlere inanmayanların, diğer bir ifadeyle tecavüzü meşrulaştırmayanların, mağdura yönelik olumlu değerlendirmeler yapmaları ve empati göstermeleri de bu argümanı destekler niteliktedir.

Bizim çalışmamızda, diğer çalışmalardan farklı olarak, mesajın içeriği büyük ölçüde olaylara dayanmaktadır (örn., kamulaştırma sürecinin başlama tarihi, yıkılan ve yıkılması planlanan ev sayısı) ve mesajda mağduriyet / dezavantaj vurgusu açık değildir. Ancak, belirsizlik durumunda önceki tutumların değerlendirmede etkili olduğu bulgusuna paralel olarak, katılımcıların olayın meşruiyetine yönelik algılarının mesajın değerlendirilmesinde etkili olabileceği ve Sur'un kamulaşt1rılmasını meşru gören katılımcıların mağdur odaklı anlatımı daha yanlı değerlendirmeleri beklenebilir. Ancak, bizim çalışmamızda olayın meşruiyetine ilişkin görüş ve mesaj odağının yanı sıra mesaj kaynağı da incelenmiştir. Literatürde mesaj kaynağı, odağı ve olayın meşruiyetine yönelik alg1 değiş̧kenlerinin birlikte ele alındığı çalışmalara rastlanmamıștır. Bu bağlamada, biz de yürüttügü̈müz çalışma kapsamında Sur'un kamulaştırılmasını meşru gören ve görmeyen katılımcıların, mesajın kaynağının ve odağının manipüle edildiği koşullarda mesajın içeriğine yönelik nasıl bir değerlendirme yapacaklarını inceleyerek, literatüre katkı sunmayı amaçladık.

\section{Kolektif Suçluluk}

Araştırmamızda Sur'un kamulaştırılmasına ilişkin verilen mesajın kaynă̆ını ve odağını manipüle ettiğimiz koşulların, mesajın değerlendirilmesinin yanı sıra kolektif suçluluk düzeyine etkisini de incelemeyi amaçladık. Politik psikoloji literatüründe kolektif suçluluk, insanların kendi gruplarını başka bir grubun gördüğü zarardan sorumlu tuttuklarında hissettikleri olumsuz bir duygu olarak tarif edilmiştir (Branscombe, Doosje ve McGarty, 2002). Kolektif suçluluk kişisel suçluluktan farklılaşır çünkü kişisel kimlikten ziyade sosyal kimlikten ve kişisel sorumluluktan ziyade kolektif sorumluluk bilincinden kaynaklanır (Ferguson ve Branscombe, 2010). Nitekim, Doosje ve ark. (1998) grup temelli suçluluk duygusunun kişisel suçluluk duygusundan farklı olduğunu yaptıkları laboratuvar çalışmasıyla da göstermişlerdir. $\mathrm{Bu}$ çalışmada katılımcılar minimal bir grubun üyesi olarak kategorize edildikten sonra, yapılan manipülasyon çerçevesinde, hem dahil oldukları grubun (iç-grup) hem de bireysel olarak kendilerinin, diğer bir gruba (dış-grup) yönelik ne düzeyde önyargıya sahip oldukları ile ilgili bilgilendirilmişlerdir. Bulgular, bireysel düzeyde önyar- gılı olmadıkları ancak dahil oldukları grubun diğer gruba yönelik önyargılı olduğu geri bildirimini alan katılımc1ların kolektif suçluluk hissettiklerini göstermiştir. Diğer bir ifadeyle, kişiler, kendileri kişisel olarak önyargı sergilememiş olsa da kolektif suçluluk hissettiklerini rapor etmiştir ve bu duygu kişisel suçluluktan farklılaşmıştır.

Telafi edici davranışlarla olumlu yönde ilişkili olan ve bu nedenle de gruplar-arası çatışma çözümünde etkili olabilecek bir değişken olan kolektif suçluluğun ortaya çıkmasına neden olan faktörler literatürde ortaya konmaya çalışılmıştır. Bizim çalışmamızda ele aldığımız iç-grupla özdeșleșme ve olayın meșruiyetine ilișkin algı, kolektif suçluluk üzerine yapılan çalışmalarda kolektif suçluluğun öncülü olarak incelenen değiş̧kenlerin en başında gelmektedir (Sakallı-Uğurlu ve Soylu, 2016). Kişilerin maruz kaldıkları bilginin kim tarafindan ve kime odaklı verildiğinin kolektif suçluluk üzerindeki etkisine yönelik de sayısı daha az olmakla birlikte çalışmalar mevcuttur. Örneğin, kişilerin dahil oldukları grupların verdiği zarara yönelik bilgi kendi grup üyelerinden geldiğinde (örn., Doosje ve ark., 2006) ve zarar görene / mağdur odaklı bir anlatımdansa, zarar veren / fail odaklı bir anlatım benimsendiğinde (örn., Imhoff, Bilewicz ve Erb, 2012) kişilerin daha yüksek düzeyde kolektif suçluluk hissettikleri gösterilmiştir.

Mesajın kaynağg. Sayısı az olmakla birlikte, mesajın kaynağının diğer bir ifadeyle mesajı kimin verdiğinin, kolektif suçluluk düzeyini etkileyen önemli bir faktör olarak incelenmesi gerektiğine işaret eden çalışmalar mevcuttur. Örneğin, yine yukarıda bahsettiğimiz Doosje ve ark.'nın (2006) Hollandalı öğrencilerle yaptıkları çaıışmada, bilgi iç-gruptan geldiği koşulda katılımcıların daha fazla kolektif suçluluk hissettikleri bulunmuştur. Ancak, mesaj kaynağının verdiği mesajın içeriği de kolektif suçluluk düzeyi üzerinde belirleyici olan bir diğer faktördür. Örneğin, Petty ve ark.'nın (2001) yaptığı çalışma mesaj kaynağının, grubunun çıkarlarına ters düşecek beklenmedik bir görüş bildirmesi durumunda mesajın daha çok dikkate alınacağına işaret etmiştir. Ayrımcı ifadelere karşı çıkan / sorgulayan kişinin avantajlı grup üyesiyse daha ikna edici, ayrımcılığa uğrayan grubun bir üyesi olduğu durumda ise daha yanlı ve daha kaba alg1lanması da (Rasinski ve Czopp, 2010), fail ya da avantaj11 gruptan gelecek mesajın daha yüksek düzeyde kolektif suçlulukla ilişkilenebileceğine işaret etmektedir.

Mesajın odă̆ı. Literatürde, mağdura $\mathrm{m} 1$ yoksa faile mi odaklanmanın daha yüksek düzeyde kolektif suçlulukla ilișkilendiğine dair çalıșmalar yürütülmüștür. Mesajın genellikle üçüncü bir ağızdan verildiği bu ça1ışmalarda olumsuz çıktıları olan eylemi gerçekleştiren faile odaklı anlatımın, bu eylemden etkilenen mağdur odaklı anlatıma kıyasla, daha yüksek düzeyde kolektif suçlulukla ilişsilendiği gösterilmiştir. Örneğin, örnek- 
lemi Almanya'daki üniversite öğrencilerden oluşan bir çalışmada Yahudi soykırımı, fail ya da mağdur odaklı anlatılmıştır (Imhoff ve ark., 2012). Faile odaklanılan metinde Alman askerlerinin Yahudileri öldürdükleri, kamp mahkumlarını soydukları ve toplu infazlar düzenlediklerine dair ifadeler yer almıştır. Mağdura odaklanılan metinde ise Yahudilerin öldürüldügüu, soyulduğu ve infaz edildiğine dair ifadelere yer verilmiştir. Katılımc1ların fail odaklı metni okuduktan sonra daha fazla kolektif suçluluk hissettikleri bulunmuştur.

Literatürde, fail-mağdur odaklı anlatımın etkisini inceleyen çalışmaların yanı sıra avantajlı-dezavantajlı grup üyelikleri üzerinden de yürütülen çalışmalara rastlanmaktadır. Örneğin bir çalışmada Beyaz Amerikalı katılımcılardan, Beyazların sahip olduğu avantajlar ya da Siyahilerin sahip olduğu dezavantajlarla ilgili ifadeleri okumaları istenmiştir (Powell, Branscombe ve Schmitt, 2005). Beyazların sahip olduğu avantajları okuyan kat1lımcıların, Siyahilerin dezavantajlarına odaklanan metni okuyanlara kıyasla, daha fazla kolektif suçluluk hissettikleri bulunmuştur. Yine benzer bir diğer çalıșmada Avrupa kökenli Amerikalıların, Afrika kökenli Amerikalılara kıyasla, sahip oldukları avantajlara odaklanmaları istendiğinde (Afrika kökenli Amerikalıların sahip oldukları dezavantajlara kıyasla) daha fazla kolektif suçluluk hissettikleri görülmüștür (Iyer, Leach ve Crosby, 2003). Kolektif suçluluğun avantajlı grubun sahip olduğu ayrıcalık ve avantajlara odaklanıldığında daha fazla deneyimlenmesi, avantajlı grup üyelerinin, diş-grubun dezavantajlarına odaklandıklarında empati hissetmeleri, ancak kendi avantajlı durumlarını sorgulamamaları ve dolayısıyla kendi grup kimliklerinin olumlu imajına yönelik tehdit hissetmemeleri ile ilişkilendirilmiştir (Lowery ve ark., 2012; Lowery, Knowles ve Unzueta, 2007).

Görüldügü gibi literatürdeki pek çok çalışma tutarlı olarak fail / avantajlı grup odaklı anlatımının avantajlı grup üyelerinin kendi pozisyonlarını sorgulamaları açısından olumlu etkisine dikkat çekmektedir. Ancak bizim çalışmamızda, mesaj kaynağı ve odağına ait bilginin birlikte verilmesi elde edilecek sonuçları etkileyebilecek önemli bir faktördür. Her ne kadar mesaj kaynağ 1 ve odağının birlikte manipüle edildiği çalışmaların sayısı az olsa da Littleford ve Jones (2017) bizim yaptığımız çalışmayla paralel sayılabilecek, ırka dayalı eşitsizliğe odaklanan bir çalışma yürütmüştür. Örneklemini Beyaz katılımcıların oluşturduğu çalışmanın bulguları mesaj kaynağı (Beyaz ya da Siyahi) ve odağının (Beyazların avantajları ya da Siyahilerin dezavantajları) birlikte manipüle edildiği koşulların kolektif suçluluk üzerinde yordayıcı etkisinin olmadığını göstermiştir. Littleford ve Jones (2017) bu bulguyu, mesaj kaynağının grup kimliğinin belirgin olduğu ve konunun etnik / 1rk kimliğiyle ilgili olduğu bir bağlamda, katılımcıların hissettikleri duyguya değil, mesajın geçerliliğini değerlendirmeye odaklanmalarıyla ilişkilendirmiştir.

Benzer şekilde, Türkiye bağlamında, 6-7 Eylül olaylarının fail, mağdur ya da nötr bir perspektiften anlatıldığı bir araştırmada ise Özkan (2014), kullanılan mesajın perspektifinin kolektif suçluluk duygusunu etkilemediği sonucuna ulaşmıştır. Özkan'ın çalışmasında, perspektif kavramı hem mesajın kaynağı hem de mesajın odağını ifade etmektedir: Özkan'ın yaptığı çalışmada mağdur perspektifi olarak adlandırılan koşulda anlatıcı mağdurdur ve mağdurların yaşadı̆̆ anlatım vardır (örn., evlerimizi, işyerlerimiz... yağmaların hedefi oldu). Fail perspektifi olarak adlandırılan koşulda ise anlatıcı faildir ve fail odaklı bir anlatım vardır (örn., ...yağmalamalarımızda azınlıkların ev, işyeri ve kurumlarını hedef aldık.). Özkan'ın yaptığı çalışmada 6-7 Eylül olaylarıyla ilgili fail ya da mağdur perspektifinden anlatımın katılımcıların kolektif suçluluk değerlerinde bir farklılaşmaya neden olmadığı sonucuna ulaşılmıştır.

Yürüttüğümüz bu çalışma, Beyaz ve Siyahilerin avantajlı / dezavantajlı konumuna odaklanan, Litteford ve Jones'un (2017) çalışmasından farklı olarak, spesifik bir olaya, Sur'daki kamulaştırmaya odaklanmaktadır. Özkan'ın (2014) çalışmasından ise güncel bir olaya odaklanması açısından farklılaşmaktadır. Ancak bizim çalışmamızda da hem mesajın kaynağı hem de mesajın odağı birlikte manipüle edildiği için, Litteford ve Jones'un (2017) ve Özkan'ın (2014) bulgulariyla paralel bulgular elde etmemiz, diğer bir ifadeyle manipüle ettiğimiz koşulların kolektif suçluluk üzerindeki etkisinin anlamlı olmaması beklenmektedir. Daha önce yürütülen çalışmaların azlığı göz önünde bulundurulduğunda, farklı bir bağlamda güncel bir olaya, Sur'un kamulaştırılmasına odaklanan bu çalışmanın konuyla ilgili bilgi birikimine katkı sunacağını düşünüyoruz.

Alıcının özellikleri. Sosyal Kimlik Kuramı'na (Tajfel ve Turner, 1986) göre, insanlar kendi iç-gruplarını pozitif görme eğilimindedirler. Dolayısıyla, bazı kişiler iç-gruplarıyla ilgili olumlu hissetmek adına, iç-grubun dış gruba verdiği zararı görmezden gelme ya da kabul etmeme gibi bazı stratejileri kullanma yoluna gidebilirler (Wohl, Branscombe ve Klar, 2006). Özellikle, iç-grupla özdeşleşmesi yüksek olan kişilerin kendi gruplarıyla ilgili pozitif imajı sürdürme konusunda daha fazla istekli olmaları da beklenen bir durumdur (Sharvit, Brambilla, Babush ve Colucci, 2015). Bu önermeler doğrultusunda, iç-grup özdeşleşmesi yükssek kişilerin, iç-grubun dış gruba verdiği zararı görmezden gelerek, daha düşük düzeyde kolektif suçluluk hissetmesi beklenebilir. Literatürde bu beklentiyi doğrulayacak bulgular mevcuttur. Örneğin, Doosje ve ark. (1998) Hollandalı ögrrencilerle yaptıkları çalışmada, iç-grupla özdeşleşmesi yüksek olan katılım- 
cıların, iç-grupla özdeşleşmesi düşük olan katılımcılara kıyasla, Hollandalıların Endonezyalıları kolonileştirmesine karşı daha az kolektif suçluluk hissettiklerini bulmuşlardır. Başka bir çalışmada (Miron ve ark., 2010), iç-grupla özdeşleşmesi yüksek olan katılımcıların kendi iç-gruplarının bir dış-gruba zarar verdiğini kabul etmeleri için daha fazla kanıt istedikleri ve bunun daha düşük düzeyde kolektif suçlulukla ilişkisi olduğu bulunmuştur.

Ancak, iç-grupla özdeşleşme ve kolektif suçluluk değişkenleri arasındaki ilişkisinin yönü ve kuvveti açısından yukarda verilen bulgularla çelişen çalışmalar da vardır. Klein, Licata ve Pierucci (2011) Belçikalılarla yürüttükleri çalışmada iç-grupla özdeşleşmesi orta düzeyde olan katılımcıların diğer katılımcılara (özdeşleşme düzeyi düşük ve yüksek) kıyasla Belçikalıların Kongo'yu kolonileştirmesine karşı daha fazla kolektif suçluluk hissettikleri sonucunu elde etmișlerdir. Özkan'ın (2014) 6-7 Eylül olayları ile ilgili yaptığı çalışmada ise Türk kimliği ile özdeşleşme ve kolektif suçluluk arasında anlamlı bir ilişki ortaya çıkmamıştır. Her ne kadar iç-grupla özdeşleşmenin kolektif suçluluk üzerindeki etkisine yönelik literatürde bazı tutarsız bulgular olsa da pek çok araştırmada (Doosje ve ark., 1998; Miron ve ark., 2010) iç-grupla özdeşleşmenin kolektif suçlulukla ilişkili bulunması bu değişkenin kolektif suçluluğun yordayıcısı olarak ele alınmasının gerekliliğine işaret etmektedir. Bu bağlamda biz de yürüttügümüz çalışmada Türk etnik kimliği ile özdeşleşme düzeyini kolektif suçluluğun belirleyicisi olabilecek bir kontrol değişkeni olarak ele aldık.

Literatürdeki bulgular dikkate alındığında, iç-grupla özdeşleşme gibi, olayın meşruiyetine yönelik algı değişkeninin de kolektif suçluluğu yordayan bir değişken olarak ele alınmasının gerekliliği ortaya çıkmaktadır (Wohl ve ark., 2006). Örneğin, Miron, Branscombe ve Schmitt' in (2006) yürüttüğü çalışma, toplumsal cinsiyet eşitsizliğini meşru görmeyen erkeklerin, cinsiyet eşitsizliğine yönelik daha fazla stres hissettiklerini ve bunun sonucu olarak da daha fazla kolektif suçluluk hissettiklerini ortaya koymuştur. Heteroseksüel erkeklerle yapılan bir başka çalışmada ise Bahns ve Branscombe (2011) eşcinsel bireylere yönelik ayrımcılığın meşruluğu onaylandığı zaman katılımcıların daha az kolektif suçluluk hissettikleri sonucuna ulaşmıştır. Yine Solak, Tagar, Cohen-Chen, Saguy ve Halperin (2017) İsrailli Yahudilerle ve Beyaz Amerikalılarla yürüttükleri iki ayrı çalışmada, iç-grubun eylemlerine ve dış-grubun uğradığg 1 zarara yönelik meşruiyet algısı azaldıkça kolektif suçluluğun arttığını bulmuşlardır. Görüldüğü gibi, literatürde yer alan çalışmalar, tutarlı olarak olayın meşruiyetine yönelik algının daha düşük düzeyde kolektif suçlulukla ilişkilendiğini göstermektedir. Bu bağlamda Sur'un kamulaşt1rılması sürecini meşru gören katılımcıların daha düşük düzeyde kolektif suçluluk hissedebileceği öngörülebilir.

\section{Araştırmanın Bağlamı: Türk-Kürt Çatışması ve Sur'un Kamulaştırılması}

İç-grupla özdeşleşme ve meşruiyet alg1sı değişkenlerinin etkisinin dikkate alınarak mesaj kaynağı ve odağının rolünün incelendiği bu çalışmanın bulgularının daha iyi yorumlanabilmesi için Sur'un kamulaştırılması ve Türk-Kürt çatışmasıyla ilgili bilgi vermek yerinde olacaktır. Asur, Pers, Roma, Bizans gibi pek çok farklı medeniyete ev sahipliği yapan Diyarbakır'da yer alan Sur Belediyesi (Öztürk, 2013) 1988 y1lında "kentsel sit alanı" olarak belirlenmiştir. Takip eden dönemlerde, imara aykırı yapılar, ruhsatsız ve riskli yapılar ve bölgedeki çatışmalar sırasında zarar gören yapılar göz önünde bulundurularak hazırlanan ya da revize edilen imar planları yürürlüğe konmuştur; buna rağmen kentin dokusu korunamamıştır (Karaaslan, 2018). Sur bölgesinin tarihi ve kültürel önemiyle de bağlantılı olarak bölgeyle ilgili alınan kararlar sıklıkla tartışma yaratmıştır. Ancak, 2016 yılında, Sur ilçesinde yer alan 6300 parsel taşınmazın riskli olduğu gerekçesiyle acele kamulaştırmasını içeren karar Sur'u halen devam etmekte olan tartışılmaların odağına taşımıştır. Karaaslana'a göre (2018) her ne kadar riskli ve ruhsatsız yapılar nedeniyle kentsel dönüşüm bölgede önemli bir ihtiyaç olsa da acele kamulaştırma kararı çerçevesinde, yerel yönetimlerin yetkilerinin sınırlandırılması, riskli alanların belirlenirken Afet ve Acil Durum Yönetimi Başkanlığı'ndan ya da bilirkişi / uzmanlardan görüş alınmaması, kamulaştırmanın 20152016 yıllarında gerçekleşen çatışmalardan zarar gören 7 mahalleyi değil diğer 11 mahalleyi de kapsaması, taşınmazların sahiplerinin bulundukları mahallere sokulmamaları, süreçle ilgili kamuoyunun bilgilendirilmemesi sürecin hukuki olarak uygunluğuna gölge düşürmüştür. Ayrıca yıkıma örgütlü bir şekilde karşı çıkmak amacıyla, sivil toplum kuruluşları, siyasi parti temsilcilerinin de yer aldığ 1 "Sur'un Yıkımına Hayır Platformu” kurulmuştur (Sur'daki yıkımlara karşı platform kuruldu, 2017).

Birleşmiş Milletler İnsan Hakları Yüksek Komiserliği tarafından yayınlanan rapora göre (OHCHR, 2017), 2015-2016 y1lında Türkiye'nin doğu ve güneydoğusunda yerinden edilen kişi sayısı 355 000- 500000 aralığındadır ve bu kişilerin büyük çoğunluğunu Sur'da yaşayan Kürtler oluşturmaktadır. Raporda ayrıca, bu süreçte bölge halkına devlet tarafindan gerekli insani yardımın yapılmadığı belirtilmiştir. Dolayısıyla, Sur'un kamulaştırılması bölgede yaşayan Kürtlerin mağduriyetiyle yakından ilişkilidir ve bu da Sur'un kamulaştırılmas1 sürecinin Türk-Kürt sorunu / çatışması bağlamında ele alınması gerektiğine işaret etmektedir.

Türk-Kürt sorunu, Türk-Kürt çatışması ya da Kürt sorunu olarak adlandırılan sorun, 1984 yılından beri 45 000 kişinin ölümüne, doğu ve güneydoğuda bir milyondan fazla insanın yerinden edilmesine neden olmuş- 
tur (Uluğ ve Cohrs, 2016). Türkiye Cumhuriyeti'nin, 1923’te kuruluşuyla birlikte, farklı etnik kimliklerin Türk kimliği altında birleştirilmesine dayanan ulusalc1 politikanın benimsenmesi, Kürt kimliğinin yok sayılmasına tepki olarak şiddet içeren eylemlerle Kürtlerin taleplerini dile getirmeyi hedefleyen Kürdistan İşçi Partisi'nin (PKK) Abdullah Öcalan öncülügüüde ortaya çıkması ve desteklenmesi halen devam etmekte olan bu çatışmanın ortaya çıkması ve devamlılığı açısından önemli olaylardır (Uluğ ve Cohrs, 2016). Ayrıca bu çatışma, Türkiye'deki en büyük azınlık grup olan Kürtlerin özellikle 1990'larda pek çok insan hakları ihlaline maruz kalmalarıyla ve faili belirlenemeyen cinayetlere kurban gitmeleriyle (Uluğ ve Cohrs, 2017); günümüzde hala günlük hayatta karşılaştıkları ayrımcılıkla baş etmek ve eşit haklar için mücadele etmek zorunda kalmalarıyla ilişkilidir (Çelebi, Verkuyten ve Smyrnioti, 2016; Çoymak, 2018; yayında). Sur'un kamulaştırılması süreci de PKK ile olan çatışmalar ve devamında devletin yürüttüğü güvenlik operasyonlarını takiben başlamıştır. Bu bağlamda, bu çalışmada genelde Türk-Kürt çatışması ve özelde Sur'un kamulaştırılması sürecinde Kürtlerin deneyimlediği mağduriyetin, çoğunluk grubu oluşturan etnik-Türkler üzerindeki etkisini gruplar-arası ilişkiler literatürü açısından incelemeyi amaçladık.

\section{Çalışmanın Alan Yazına Katkısı}

Hovland ve ark. (1953) bir mesajin etkisinde, mesajı kimin verdiği, mesajın içeriği, hangi yolla mesajın iletildiği ve alıcının kim olduğu gibi değişkenlerin ortak etkisine işaret etmiştir. Ancak, bu değişkenlerin hepsini ya da birkaçını bir arada inceleyen çalışmaların sayısı oldukça azdır. Oysa bu değişkenlerin birlikte ele alınarak ortak etkilerinin incelenmesi, her gün maruz kaldığımız farklı kaynaklardan gelen mesajların / bilgilerin üzerimizde bıraktığı etkiyi daha geniş bir çerçevede anlamamıza olanak tanıyacaktır. Yürüttüğümüz bu çalışmada, mesaj kaynağı, mesaj odağı ve alıcıya ilişkin özelliklerin hep birlikte ele alınarak inceleniyor olması çalışmanın literatüre yapacağı katkı açısından önemlidir.

Ayrıca, daha önce yapılan çalışmalarda, genellikle geçmişte yaşanan olaylara (örn, Imhoff ve ark., 2012; Özkan, 2014) ya da genel olarak grupların sahip olduğu avantaj ya da dezavantajlara (örn., Harth, Kessler ve Leach, 2008; Iyer ve ark., 2003) vurgu yapılmıştır. Bu çalışmada ise, halen devam etmekte olan ve dolayısıyla mağdurların gördüğü zararla ilgili çok net bir tablonun henüz ortaya çıkmadığı bir bağlamın ele alındığı söylenebilir. Bazı araştırmacılar geçmiş, süreğen ve gelecekte oluşabilecek zararın farklı düzeyde kolektif suçluluk hissedilmesine neden olabileceğini ve konuyla ilgili araştırmaların artması gerektiğine dikkat çekmişlerdir (Sakall1-Uğurlu ve Soylu, 2016). Bu anlamda, çalışmada hala devam etmekte olan bir sürecin inceleniyor olması açısından da literatüre anlamlı katkı sunacağını düşünüyoruz.

Ayrıca, katılımcıların okudukları metnin sonunda, mahalle sakinlerinin evlerinden çıkmak istemediklerini söyleyerek, olaydaki mağduriyetlerine atıfta bulunsak da diğer çalışmalardan farklı olarak katılımcılara Sur'daki kamulaştırma sürecinin ne zaman başladığı, şimdiye kadar kaç evin yıkıldığ 1 ve kaç evin yıkılmasının planland1ğ1, mülk sahiplerine kira ve nakliye ücreti karşılama sözü verildiği gibi bilgilerin yer aldığ1, kişinin öznel görüşüne yer verilmeyen metinler sunduk. Buradaki amacimız, olaylara dayanan, objektif diyebileceğimiz bilgilerin verildiği durumda mesajın kaynağı ve odağının etkisini görmekti.

Basın yayın organları aracılı̆̆ ya da sosyal medya üzerinden maruz kaldığımız mesaj ya da bilgilerde genellikle mesajın kaynağının etnik kimliği açık olarak belirtilmez. Biz de bu nedenle konuyu gruplar-arası ilişkiler literatürü bağlamında ele alsak da mesaj kaynağının etnik kimliğini açık olarak katılımcılara sunmadık. Şimdiye kadar yürütülen mağdur ve failin yer aldığ 1 cinsel şiddet (örn., Bohner, 2001) ya da etnik kimlikle (örn., Imhoff ve ark., 2012; Özkan, 2004) ilgili çalışmalarda genellikle mağdur ve failin cinsiyeti ya da etnik kimliği açıktır. Bizim çalışmamızda ise katılımcıların, fail ve mağdurun etnik kimliğine yönelik çıkarımda bulunacakları düşünülse de sunulan metinlerde doğrudan mesaj kaynağının etnik kimliğine vurgu yapmadık ve katılımcılara bölge halkından biriyle ya da kamulaştırma sürecinden sorumlu biriyle yapılan mülakatı sunduğumuzu belirttik. Bu bağlamda, mesaj kaynağı ve odağının manipülasyonu açısından çalışmanın diğer çalışmalardan bir ölçüde farklılaştığını söyleyebiliriz.

Araştırmada değişkenlerin nasıl ele alındığ 1 kadar, yoğun olarak Kürtlerin yaşadığı bölgelerdeki güncel olay / çatışmalara yönelik yürütülen çalışma sayısının azlığı da Sur'un kamulaştırmasına yönelik yürüttüğümüz çalışmanın önemini artırmaktadır. Çalışmanın gerçek gruplarla yapılmış olması nedeniyle bulguların, tutum değişimi, çatışma çözümü için uygulanacak stratejilerin, müdahale programlarının oluşturulmasına katk1 sağlayabileceği düşünülmektedir.

\section{Yöntem}

\section{Örneklem}

Çalışma kapsamında 467 kişiye ulaştık. Ancak, çalışmayı tamamlamayan 106 kişi ve etnik kimliğini Kürt olarak tanımlayan 9 kişi, Arap olarak tanımlayan 4 kişi ve Alman olarak tanımlayan 1 kişi çıkarıldığında geriye 347 kişi kalmıştır. Etnik kimlik sorusunu boş bırakan ya da Türkmen, Balkan göçmeni, Tatar, dünya vatan- 
daşı gibi cevaplar veren katılımcıları, Türk kimliği ile özdeşleşmenin değerlendirildiği iç-grupla özdeşleşme ölçeğindeki sorulara verdikleri yanttlara göre veri setinden çıkarıp çıkarmamaya karar verdik. Bu kararda, bazı katılımcılardan veri toplama aşamasında etnik kimliğin ne olduğuna dair gelen sorular etkili olmuştur. Kendini Türk olarak gören ancak etnik kimliğin ne anlama geldiğinden tam olarak emin olamayan katılımciların soruları boş bırakabileceği ya da göç ettiği ya da ailesinin yaşadığı bölge nedeniyle kendini göçmen, Ankaralı ya da Türkmen olarak ifade edebileceğini düşünerek, bu katılımcıların Türk kimliği ile özdeşleşme ölçeğindeki sorulara verdikleri yanıtları inceledik ve bu sorulara uygun değil ya da 1 (kesinlikle katılmıyorum) cevabı vermedikleri takdirde çalışmaya dahil ettik. İç-grupla özdeşleşme ölçek maddelerine verdikleri yanıtların incelenmesi sonucunda, etnik kimlik sorusunu boş birakan ya da dünya vatandaşı gibi cevaplar veren 7 katılımcı daha veri setinden çıkarılmıştır ve geriye 340 katılımcı kalmıştır. Katılımcıların 254'ü kadın ve 66'sı erkektir, 2 kişi cinsiyetini belirtmek istemediğini söylemiş ve 18 kişi bu soruya cevap vermemiştir. Katılımcıların yaşları 17 ve 56 arasında değişmiştir ( Ort. $=22.31, S=5.10)$. Katılımcilardan mezun oldukları, eğitimleri devam ediyorsa devam ettikleri eğitim kurumunu yazmalarını istedik. Katılımcıların 3'ü lise, 7'si yüksekokul, 15'i yüksek lisans / doktora ve 297'si üniversite seçeneğini işaretlemiştir, 18 kişi ise bu soruya cevap vermemiştir. Katılımcıların \% 84.4'ü öğrencidir ve 268 katılımcı çalışmaya bir ders kapsamında katılarak bonus puan almıştır.

\section{Veri Toplama Araçları ve İşlem}

Çalışma için, öncelikle Başkent Üniversitesi Sosyal ve Beşeri Bilimler ve Sanat Araştırma Kurulu'ndan etik onay aldık ve devamında çalışmayı çevrimiçi veri toplama programı Qualtrics'te hazırladık. Çalışmayı sosyal medya hesaplarından duyurduk ve ayrıca siniflarda çalışmanın duyurusunu yaparak, öğrencilere bonus puan karşıllğında uyguladık. Katılımcıların internet üzerinden tamamladıkları bu çalı̧̧mada, uygun örnekleme ve kartopu örnekleme yöntemlerini kullandık. Çalışmaya başlamadan önce katılımc1lara bilgilendirme formu sunduk. $\mathrm{Bu}$ formda çalışma kapsamında Sur'daki kamulaştırma sürecinin gruplar-arası ilişkiler açısından değerlendirileceğini ve çalışmaya kendini Türk olarak tanımlayan kişilerin katılmasının beklendiğini belirttik. Çalışmaya gönüllü olarak katılmayı kabul eden katılımcılara Sur'daki kamulaştırma süreciyle ilgili, bilginin kimin tarafindan verildiğini ve odağını manipüle ettiğimiz bir metin sunduk ve onlardan takip eden kisımda detaylı olarak ve s1rasıyla verilen ölçekleri doldurmalarını istedik.

Verilen bilgide mesaj kaynağı ve odağının manipülasyonu. Katılımcılardan Sur'daki kamulaştırma süreciyle ilgili bir metni okumalarını istedik. Katılımcıların okuyacağı metinleri, Sur'daki kamulaştırma sürecine ilişkin yayınlanan bir haberde (Kamer, 2017) değişiklikler yaparak oluşturduk. Verilen bilginin manipülasyonu için katılımcıların okuduğu metindeki bilgileri sabit tutarak, sadece bilgileri kimin verdiği ve verilen bilgilerde kimin odakta olduğuna ilişkin değişiklikler yaptık. Mesaj kaynağının fail olduğu koşullarda, yapılan mülakatın Sur'daki kamulaştırma sürecinden sorumlu kişilerden biriyle yapıldığını, mesaj kaynağının mağdur olduğu koşullarda ise mülakatın Sur'daki bölge halkından biriyle yapıldığını belirttik. Odak dikkate alındığında ise, odağın fail olduğu koşullarda kamulaştırma sürecinden sorumlu kişilerin eylemlerine odaklı bir anlatım, odağın mağdur olduğu koşullarda ise bölge halkının deneyimlerine odaklanan bir anlatımı benimsedik. Fail odaklı anlatımda aktif cümle yapısı, mağdur odaklı anlatımda ise pasif cümle yapısını ağırlıklı olarak kullandık. Çalışma kapsamında mesaj kaynağının fail olduğu fail odaklı anlatım (örn., Kamulaştırma sürecinden sorumlu kişilerden biri: “...altı mahallede 75.3 hektarlık alanın 46.3 hektarlık bölümünü yıktık.” “....mahallelerindeki evlerin kalan kısmını da bu karar doğrultusunda boşaltıp yıkıyoruz"; “...evlerin çoğunda su ve elektriği kestik”), mesaj kaynağının fail olduğu mağdur odaklı anlatım (örn., Kamulaştırma sürecinden sorumlu kișilerden biri: ““ “...altı mahallenin 75.3 hektarlık alanın 46.3 hektarlık bölümü yıkıldı” “....mahallelerindeki evlerin kalan kısmı da bu karar doğrultusunda boşaltılıp yıkılıyor”; “...evlerin çoğunda su ve elektrik kesildi”), mesaj kaynağının mağdur olduğu mağdur odaklı anlatım (örn., Bölge halkından biri: “...altı mahallemizin 75.3 hektarlık alanın 46.3 hektarlık bölümü yıkıldı" "...mahallelerindeki evlerin kalan kısmı da bu karar doğrultusunda boşaltılıp yık1lyyor"; ...evlerimizin çoğunda su ve elektrik kesildi”) ve mesaj kaynağının mağdur olduğu fail odaklı anlatım (örn., Bölge halkından biri: “...altı mahallemizdeki 75.3 hektarlık alanın 46.3 hektarlık bölümünü yıktılar”, “... mahallelerimizdeki evlerin kalan kısmını da bu karar1 gerekçe göstererek boşaltıp yıkıyorlar”, “...evlerin çoğunda su ve elektriği kestiler") olmak üzere 4 farklı metin oluşturduk. Katılımcılarımızı bu 4 farklı koşuldan birine seçkisiz olarak atadık.

Mesaja ilişkin değerlendirme. Katılımc1lar 1'den (kesinlikle katılmiyorum) 7'ye (kesinlikle katıllyorum) kadar derecelendirilmiş iki soru ile yapılan mülakatın ne derece doğru bilgiler içerdiğini (Yapılan mülakatın doğru bilgiler içerdiğini düşünüyorum) ve yanlılı̆̆ını (Surdaki kamulaştırma süreciyle ilgili yapılan bu mülakatın yanlı olduğunu düşünüyorum) değerlendirmişlerdir. Maddelerin yüksek korelasyonu nedeniyle $(r=-.50, p<$ .001 ), öncelikle mülakatın yanlılığına ilişkin soruyu ters çevirdik ve daha sonraki analizler için bu iki maddenin 
Tablo 1. Mesajın Doğru / Yansız Değerlendirmesinde Mesajla İlgili Koşullar ve İç-Grupla Özdeşleşme Değişkenlerine Göre Karşılaştırma Sonuçları

\begin{tabular}{llllllc}
\hline & & & & \multicolumn{2}{c}{ \% 95 Güven Aralığı } \\
\hline Koşullar & $\begin{array}{l}\text { İç-grupla } \\
\text { Özdeşleşme }\end{array}$ & $N$ & Ort. & $S$ & Alt Sınır & Üst Sınır \\
\hline Kaynak: Fail & Düşük & 41 & 3.88 & 1.27 & 3.50 & 4.26 \\
Odak: Fail & Yüksek & 35 & 3.79 & 0.97 & 3.37 & 4.20 \\
\hline Kaynak: Mağdur* & Düşük & 35 & 4.61 & 1.41 & 4.20 & 5.03 \\
Odak: Fail & Yüksek & 45 & 3.77 & 1.21 & 3.40 & 4.13 \\
\hline Kaynak: Fail & Düşük & 50 & 4.10 & 1.34 & 3.75 & 4.45 \\
Odak: Mağdur & Yüksek & 34 & 4.19 & 1.13 & 3.77 & 4.61 \\
\hline Kaynak: Mağdur ** & Düşük & 42 & 5.10 & 1.21 & 4.72 & 5.47 \\
Odak: Mağdur & Yüksek & 45 & 3.68 & 1.28 & 3.31 & 4.04 \\
\hline
\end{tabular}

${ }^{*} p<.01,{ }^{*} * p<.001$

aritmetik ortalamasını alarak devam ettik. Bu değişkendeki yüksek puanlar mülakatın daha doğru / yansız alg1landığ 1 anlamına gelmektedir.

Olayın meşruluğuna ilişkin sorular. Sur ilçesindeki mahallelerin kamulaştırılmasının ne derece meşru algılandığını "Sur ilçesindeki mahallelerin kamulaşt1r1lmasıyla ilgili sürecin haklı ve adil olduğunu düşünüyorum.", "Surdaki evlerin kamulaştırılmasının var olan sorunu çözmek için iyi bir yol olduğunu düşünüyorum" ve "Surdaki evlerin kamulaştırılmasının var olan sorunu çözmeye katk1 sağlayacağını düşünüyorum." olmak üzere üç madde ile değerlendirdik. 1'den (kesinlikle katılmıyorum) 7'ye (kesinlikle katılıyorum) kadar derecelendirilmiş ölçeğin Cronbach alfa katsayısını .83 olarak elde ettik. Bu değişkendeki yüksek puanlar olayın meşru algılandığı anlamına gelmektedir

Kolektif suçluluk ölçeği. Kolektif suçluluğu değerlendirmek için, Doosje ve ark.'nın (1998) oluşturduğu Özkan (2014) tarafından Türkçeye çevrilen, 1'den (kesinlikle katılmıyorum) 7'ye (kesinlikle katılıyorum) kadar derecelendirilmiş, 6 maddelik kolektif suçluluk ölçeğini kullandık. Ölçekte yer alan soruları çalışma kapsamında ele aldığımız konu çerçevesinde düzenledik; örn., "Sur'un kamulaştırılma sürecinde Türklerin Kürtlere yönelik zarar verici davranışları yüzünden suçluluk duyuyorum”. Ölçek maddelerinin tümü ele alındığında, ölçeğin Sur'daki Kamulaştırma süreci, Türklerin Kürtlere yönelik zarar verici davranışları ve Türk olmanın getirdiği faydalardan katılımcıların duyduğu suçluluğa yönelik bir değerlendirme sunduğu söylenebilir. Diğer bir ifadeyle bu ölçekte hem Sur'un kamulaştırılması hem de Kürtlerin genel olarak olumsuz deneyimlerine yönelik hissedilen suçluluk hissini değerlendirdik. Ölçeğin Cronbach alfa katsayısını .88 olarak bulduk. Bu değişkendeki yüksek puanlar yüksek kolektif suçluluk deneyimlendiği anlamına gelmektedir

İç grupla özdeşleşme ölçeği. Türk kimliği ile özdeşleşmeyi, Bohner, Siebler, Gonzalez, Haye ve Schmidt'in (2008) çalışmalarında kullandığı "Kendinizi ne kadar Türk olarak görüyorsunuz?”, “Türk olmaktan ne kadar memnunsunuz?" ve "Türk olmak sizin için ne kadar önemli?" sorularını içeren üç maddelik ölçek ile değerlendirdik. Birden (hiç) 5'e (çok) kadar derecelendirilmiş bu ölçeğe, soruların kendileri için uygun olmad1ğını düşünen katılımcılar için “Uygun Değil”" seçeneğini de ekledik. Her ne kadar bilgilendirilmiş onam formunda kendini Türk olarak tanımlayan kişilerin çalışmaya katılmasını beklediğimizi belirtsek de onam formunu dikkatle okumama, soruları merak etme gibi nedenlerle kendisini Türk olarak tanımlamayan ve / veya farklı etnik gruplara mensup kişilerin tespit edilebilmesi için seçeneklere uygun değil seçeneğini de ekledik. Ölçeğin Cronbach alfa katsayısını .86 olarak elde ettik. Bu değişkendeki yüksek puanlar Türk kimliğiyle yüksek düzeyde özdeşleşme anlamına gelmektedir

Kişisel bilgi formu. Bu kısımda katılımcılara yaşları, cinsiyetleri ve eğitim durumlarına ilişkin sorular sorduk.

\section{Bulgular}

\section{Mesajın Değerlendirilmesine İlişkin Bulgular}

Mesajın kaynağı ve odağını manipüle ederek oluşturduğumuz 4 farklı koşulda, etnik-Türk kimliğiyle özdeşleşme skorları düşük ve yüksek katılımcıların mülakatın içeriğine yönelik yaptıkları değerlendirmeleri karşılaştırmak için, öncelikle ortanca ayrıştırma (median split) yöntemi kullanılarak Türk kimliği ile özdeşleşmesi 
Tablo 2. Mesajın Doğru / Yansız Değerlendirmesinde Mesajla İlgili Koşullar ve Meşruiyet Algısı Değişkenlerine Göre Karşılaştırma Sonuçları

\begin{tabular}{llllllc}
\hline & & & & & \multicolumn{2}{c}{ \% 95 Güven Aralığı } \\
\hline Koşullar & Meşruiyet & $N$ & Ort. & $S$ & Alt Sınır & Üst Sınır \\
\hline Kaynak: Fail & Düşük & 35 & 3.64 & 1.17 & 3.21 & 4.08 \\
Odak: Fail & Yüksek & 46 & 3.92 & 1.13 & 3.55 & 4.30 \\
\hline Kaynak: Mağdur & Düşük & 47 & 4.22 & 1.46 & 3.85 & 4.60 \\
Odak: Fail & Yüksek & 35 & 3.97 & 1.24 & 3.53 & 4.40 \\
\hline Kaynak: Fail & Düşük & 41 & 4.10 & 1.45 & 3.70 & 4.50 \\
Odak: Mağdur & Yüksek & 47 & 4.21 & 1.08 & 3.84 & 4.59 \\
\hline Kaynak: Mağdur * & Düşük & 47 & 4.72 & 1.44 & 4.35 & 5.10 \\
Odak: Mağdur & Yüksek & 42 & 3.98 & 1.35 & 3.58 & 4.37 \\
\hline
\end{tabular}

$* p<.01$

düşük ve yüksek olan grupları oluşturduk. Sonrasında yaptığımız 2 X 4 Faktöriyel ANOVA sonuçları, manipüle ettiğimiz koşulların $(F(3,319)=2.73, p=.04$, kısmi $\eta 2=.03)$ ve Türk kimliği ile özdeşlemenin $(F(1,319)=$ $16.71, p<.001$, k1smi $\eta 2=.05)$ temel etkisinin ve bu iki değişkenin etkileşimli etkisinin $(F(3,319)=6.54, p$ $<.001$, kısmi $\eta 2=.06$ ) anlamlı olduğuna işaret etmiştir. Bonferroni uyarlaması ile yaptığımız analiz sonrası karş1laştırmalar, Türk kimliğinin temel etkisi dikkate alındığında, Türk kimliğiyle özdeşleşmesi düşük katılımc1ların $($ Ort. $=4.42)$, yüksek olanlara kıyasla $($ Ort. $=3.86)$ okudukları metnin daha doğru / yansız olduğunu düşündüklerini göstermiştir $(p<.001)$. Mesajla ilgili koşulların etkisine baktığımızda ise failin fail odaklı anlatımı ile (Ort. $=3.83)$, mağdurun mağdur odaklı anlatımının $($ Ort. $=4.39)$, anlamlı olarak farklılaştığ $1(p=.03)$; mağdurun mağdur odaklı anlatımının daha doğru / yansız algılandığ1 görülmüştür. Türk kimliği ile mesajın kaynağ1 ve odağ1 çerçevesinde manipüle ettiğimiz koşulların etkileşimli etkisine baktığımızda ise, mesaj kaynağının mağdur olduğu hem mağdur hem de fail odaklı koşullarda Türk kimliği ile özdeşleşme skorları düşük ve yüksek olan katılımcıların mülakatın içeriğine yönelik değerlendirmelerinin farklı olduğu ortaya çıkmıştır. Daha açık bir ifadeyle, Türk kimliğiyle özdeşleşme düzeyi düşük katılımcılar, bölge halkından birinin, hem fail (eylemi gerçekleştirenler) hem de mağdur (bölge halkı) odaklı anlatımını, Türk-etnik kimliğiyle özdeşleşme skorları yüksek katılımcılara kıyasla, daha doğru / yansız değerlendirmişlerdir (Bkz. Tablo 1).

Türk kimliği ile özdeşleşme gibi, olayın meşruiyetine yönelik algının da mesajın kaynağı ve odağını manipüle ederek oluşturduğumuz 4 farklı koşulun etkisinde belirleyici rolünü incelemek için öncelikle ortanca ayrıştırma (median split) yöntemi kullanılarak olayın meşruiyetine yönelik algının düşük ve yüksek olduğu grupları yarattık ve sonrasında 2 X 4 Faktöriyel ANOVA ile analiz ettik. Bulgular, manipüle ettiğimiz koşulların $(F(3,332)=2.71, p=.04$, k1smi $\eta 2=.02)$ anlaml etkisine işaret etmiştir. Meşruiyet değişkenin temel etkisi ise anlamlı değildir $(F(1,332)=1.12, p=.29$, kısmi $\eta 2$ $=.00)$ ancak meşruiyet algısının manipüle ettiğimiz koşullarla etkileşimli etkisi $(F(3,332)=2.63, p=.05$, k1smi $\eta 2=.02)$ sınırda anlamlılık göstermiştir. Mağdurun mağdur odaklı açıklama yaptığı yani bölge halkından birinin, bölge halkına odaklı mesajında, Sur'un kamulaştırılmasının meşru olmadığını düşünen katılımcılar, meşru olduğunu düşünen katılımcılara kıyasla, yapılan mülakatın içeriğini daha doğru / yansız bulmuşlardır (Bkz. Tablo 2).

\section{Kolektif Suçluluğa İlişkin Bulgular}

İç-grupla özdeşleşme ve olayın meşruiyetine dair algıyı kontrol değişkenleri olarak alıp, mesajın kaynağ ve odağını birlikte manipüle ettiğimiz bilginin verilişindeki farklılıkların kolektif suçluluğu nasıl etkilediğini Tek Yönlü ANCOVA analizi ile test ettik. Bulgular, kontrol değişkenlerinin etkisi dikkate alındığında, verilen bilgideki mesajın kaynağı ve mesajın odağı ile ilgili manipülasyonun kolektif suçluluk üzerinde de anlamlı bir etkiye sahip olmadığını gösterdi $(F(3,216)=1.86, p$ $=.14$, kısmi $\eta 2=.03)$. Kontrol değişkenlerinin kolektif suçluluk üzerindeki etkisine baktığımızda ise, Türk kimliği ile özdeşleşmenin $(F(1,216)=5.52, p=.02$, k1smi $\eta 2=.03)$ ve olayın meşruiyetine dair algının $(F(1,216)=$ $32.15, p<.001$, k1smi $\eta 2=.13$ ) daha düşük düzeyde kolektif suçlulukla ilişkili olduğu sonucuna ulaştık. Daha açık bir ifadeyle, bulgulara göre, Türk kimliğiyle özdeş- 
leşme düzeyi yükseldikçe ve Sur'un kamulaştırılmasıyla ilgili meşruiyet algısı arttıkça, katılımcıların Sur'un kamulaştırılması ve Türklerin Kürtlere yönelik zarar verici davranışları nedeniyle daha az kolektif suçluluk hissettikleri ortaya çıkmıştır.

\section{Tartışma}

\section{Mesaja İlişkin Değerlendirme}

Yaptığımız bu çalıșmada, mesajın kaynağı ve odağını manipüle ederek oluşturduğumuz farklı koşulların, Türk kimliği ile özdeşleşme ve olayın meşruiyetine yönelik alg1 değişkenlerinin, mesajın değerlendirilmesi üzerindeki temel etkisini ve ayrıca manipüle ettiğimiz koşulların Türk kimliği ile özdeșleșme ve olayın meșruiyetine yönelik alg1 değişkenleri ile ortak etkisini inceledik.

Temel etkilere baktığımızda, Türk kimliği ile özdeşleşme düzeyi yüksek katılımcıların Sur'un kamulaştırılmasıyla ilgili verilen bilgileri daha yanlı algıladıklarını fakat olayın meşruiyetine yönelik alg1 değişkeninin, mesajın değerlendirilmesi üzerinde bir etkisinin olmad1ğını gördük. Mesajın kaynağı ve odağını manipüle ettiğimiz koşulların temel etkisine baktığımızda ise mağdurun mağdur odaklı anlatımının, failin fail odaklı anlatımına kıyasla daha doğru / yansız algılandığını gördük. Elde edilen bulgu, katılımcıların failin yaptığı açıklamayı grubun çıkarlarına ters düşerek sorumluluk almasıyla ya da süreçten bireysel ya da grubu adına çıkar sağlamak istemesiyle ilişkilendirmeleriyle ilgili olabilir. Ancak, yap1lan çalışmaların sayısının azlığı da göz önünde bulundurulduğunda, bulguların daha sağlıklı yorumlanması için mesaj kaynağının motivasyonuna ilişkin katılımcıların yapmış oldukları atıflara ilişkin gelecekte yürütülecek çalışmalara ihtiyaç vardır.

Literatürde, mağdurdan / dezavantajlı grup üyesinden gelen mesajların fail / avantajlı grup üyesi tarafından ortaya konan görüşlerden daha yanlı algılandığını gösteren çalışmaları düşündüğümüzde (Gulker ve ark., 2013), elde ettiğimiz bulgunun literatürle tutarsız olduğu düşünülebilir. Ancak çalışmamızda, failin fail odaklı anlatımında, kamulaştırma sürecinden sorumlu kişinin kurduğu “...altı mahallede 75.3 hektarlık alanın 46.3 hektarlık bölümünü yıktık.” “...evlerin çoğunda su ve elektriği kestik” gibi cümlelere ilişkin katılımcıların yapmış olduğu atıflar sonuçların yorumlanması açısından önemlidir. Failin fail odaklı mesajında kullanılan aktif cümle yapısı, eylemi gerçekleştirene sorumluluk atfının yapılmasıyla ilişkilidir (Platow ve Brodie, 1999). Bu durumda, katılımcılar çatışma, insan hakları ihlalleri, bölge halk1nın mağduriyeti ile ilişkilenen bu olayda, failin grubunun çıkarlarına ters düşerek, sorumluluğu kendisinin ya da grubunun üzerine aldığını düșünebilirler. Petty ve ark. (2001) mesaj kaynağının grubunun çıkarlarına ters düşe- cek bir görüş ortaya koyduğu durumunda, alıcının, mesaj kaynağının bu açıklamayı yapma motivasyona yönelik yapacağı atıftaki belirsizlik nedeniyle, kaynağı daha az güvenilir algıladığını göstermiştir. Diğer yandan katılımcılar, failin fail odaklı anlatımını, failin yapılan eylemin meşruiyetine inanarak kendisi ya da grubu adına çıkar sağlamaya çalışmasıyla da ilişkilendirmiş ve bu nedenle yanlı algılamış olabilirler.

Elde edilen sonucun daha sağlıklı yorumlanabilmesi için, böyle bir metni okuduklarında, katılımcıların mağdurun ve failin açıklamalarının temelinde yatan motivasyonu nasıl yorumladığını anlamak gerekmektedir ve bu bağlamda gelecekte yürütülecek çalışmalara ihtiyaç vardır. Yürüttüğümüz bu çalışmada, katılımcıların çoğunluğunu öğrenciler oluşturmaktadır ve katılımcıların kamulaştırma kararı alan hükümete ne derece yakınlık duydukları bilinmemektedir. Daha sonra konuya ilişkin yürütülecek çalışmalarda farklı demografik özelliklere ve farklı politik görüşlere sahip katılımcılara ulaşılması elde edilen bulguların daha geniş çerçevede yorumlanmasını sağlayacaktır.

Manipüle ettiğimiz dört koşul karşılaştırıldığında, sadece mağdurun mağdur odaklı anlatımı ile failin fail odaklı anlatımının birbirinden farklılaşması da üzerinde düşünülmesi gereken bir bulgudur. Mağdurun kendi deneyimlerine odaklı mesajının, failin fail odak11 anlatımına kıyasla daha doğru ve yansız algılanmas1, okuyucuların mağdurun söylemine güven duymasıyla ilişkilendirilebileceği gibi katılımcıların mağdurun mesajını yanlı değerlendirip ayrımcı görünmek istememe motivasyonuyla, diğer bir ifadeyle sosyal hoş görünme [social desirability] etkisiyle de ilişkilendirilebilir. İleride yürütülecek çalışmalarda, sosyal hoş görünme etkisini kontrol etmek için, mesaja yönelik değerlendirmelerin açık ölçüm yöntemlerinin yanı sıra mesajın okunması sırasında gösterilen fizyolojik reaksiyonlar gibi örtük ölçüm yöntemleriyle de değerlendirilmesi önerilebilir.

Mesajın kaynağı ve odağını manipüle ettiğimiz koşulların Türk kimliğiyle özdeşleşme değişkeni ile ortak etkisine baktığımızda ise, bulgular mesaj kaynağının mağdur olduğu hem fail hem mağdur odaklı metinlerin, Türk kimliğiyle özdeşleşme düzeyi yüksek katılımcılar tarafından daha yanlı değerlendirildiğini göstermiştir. Diğer bir ifadeyle, Türk kimliği yüksek katılımcılar, düşük olanlara kıyasla, mağdurdan gelen bilgiyi daha yanlı değerlendirmişlerdir. Bu bulgu Doosje ve ark.'nın (2006) iç-grupla özdeşleşmesi yüksek kişilerin dış-gruptan gelen bilgiyi daha yanlı değerlendirdiklerini gösteren çalışmalarıyla ve bu doğrultuda çalışma kapsamında önerdiğimiz hipotezle tutarlıdır. Bu bulgu, Türk kimliğiyle özdeşleşmesi yüksek katılımcıların, mesajın odağından bağımsız olarak, mağduru güvenilir bir kaynak olarak görmediklerini ortaya koymaktadır. 
Çalışma kapsamında olayın meşruiyetine yönelik algı değişkeninin de manipüle ettiğimiz koşullarla etkileşimine baktığımızda Türk kimliği değişkeni için elde ettiğimiz sonuçlarla paralel olarak, bulgular Sur'un kamulaştırılmasının meşru olduğunu düşünen katılımcıların, meşru olmadığını düşünen katılımcılara kıyasla, mağdurun mağdur odaklı anlatımını daha yanlı değerlendirdiklerini göstermiştir. İç-grupla özdeşleşmenin belirleyici olduğu, mağdurun fail odaklı anlatımı koşulunda, meşruiyet algısının düzenleyici rolü anlamlı çıkmamıştır. Yine de elde ettiğimiz bulgular, Türk kimliğiyle özdeşleşme ve olayın meşruiyeti dikkate alındığında, Türk kimliğiyle özdeşleşme düzeyi yüksek ve olayın meşruiyetine inanan kişilerin mağduru güvenilir bir kaynak olarak görmediği anlamı taşımaktadır. Bir başka ifadeyle, Kürtlerin mağduriyetiyle ilişskilenen bu olayla ilgili bilgi veren kişi bölge halkından biriyse, Türk kimliğiyle özdeşleşmesi yüksek kişiler, Türk kimliğiyle özdeşleşmesi düşük kişilere k1yasla ve Sur'un kamulaştırılmasını meşru gören kişiler, meşru görmeyen kişilere kıyasla verilen mesajı daha yanlı değerlendirmişlerdir. Bulguları, ele aldığımız Türk-Kürt çatışması bağlamında düşündügüumüzde, Kürtlerin mağduriyet yaşadığı olaylarda (örn., Kürtlerin yoğun olarak yaşadığı şehirlerdeki belediyelere kayyum atanması) mağduriyet yaşayan kişi / grup üyelerinden gelen mesajları, Türk kimliğiyle özdeșleșen ve olayı meşru gören kişilerin yanlı olarak değerlendireceği ortaya çıkmaktadır.

Tutum değişimine yönelik stratejiler ve çatışma çözümüne yönelik geliştirilecek müdahale programları açısından bu bulguyu değerlendirdiğimizde, etnik- Türk kimliğiyle özdeşleşme düzeyi yüksek ve yaşanan mağduriyetin meşru olduğunu düşünen kişiler / gruplarla çalışırken, mesaj kaynağı olarak mağdur / dezavantajlı grup üyelerinin kullanılması durumunda, mesaj kaynağının yanlı algılanacağı göz önünde bulundurulmalı ve bu yanlılık algısını azaltacak önlemler alınmalıdır. Mağdurun görüşünün başka bir kaynak tarafından ya da istatistiklerle doğrulanması gibi yöntemlerin mağdurun güvenilirliğini artırabileceği düşünülebilir. Ancak bu yöntemlerin ileriki çalışmalarda ne derece etkili olduğunun tespit edilmesi gerekmektedir. Elde ettiğimiz bulguların ayrıca, dezavantajlı grubun mağduriyetiyle ilgili iletmek istediğimiz mesajlarda, avantajlı grup üyelerinin desteğinin önemine işaret ettiği de düşünülebilir: İç- grup kimliği yüksek ve dezavantaj yaratan durumun meşru olduğunu düşünen katılımcıların mağduru yanlı algılayacağı göz önünde bulundurulduğuna, mağdurun ilettiği mesajın avantajlı grup üyeleri tarafından da desteklenmesi, mesajla ilgili yanlılık algısının ortadan kalkmasını ya da azalmasını sağlayabilir. Bu yöntemin etkililiğinin de yine gelecek çalışmalarda incelenmesi, mağdurun mesaj kaynağı olarak güvenilirliğini artıracak yöntemlerin tespiti açısından önemlidir.

\section{Kolektif Suçluluk}

Yürüttüğümüz çalışmada, iç-grupla özdeşleşme ve olayın meşruiyetine iliş̧in algı değişkenlerinin kolektif suçluluk üzerindeki etkisini kontrol ederek, mesajın kaynağı ve odağını manipüle ederek oluşturduğumuz koşulların kolektif suçluluk üzerindeki etkisini araştırdık. Elde ettiğimiz bulgular, iç-grupla özdeşleşme ve olayın meşruiyetine ilişkin alg1 değişkenlerinin etkisi kontrol edildiğinde, mesajın kaynağı ve odağını manipüle ederek oluşturduğumuz koşulların etkisinin anlamlı olmadığını göstermiştir.

Her ne kadar literatürde mesajın kaynağı ve odağ1nın ayrı ayrı manipüle edildiği durumlarda, bu değişkenlerin kolektif suçluluk üzerinde belirleyici olduğunu gösteren çalışmalar mevcutsa da Özkan (2014) ve Litteford ve Jones'un (2017) yürüttüğü yakın tarihli çalışmalar kolektif suçluluk değişkenini yordamada, mesajın kaynağ1 ve odağının birlikte manipüle edildiği koşulların anlamlı etkisi olmayacağına işaret etmiştir. Littleford ve Jones (2017) bu durumu, mesaj kaynağının grup kimliğinin belirgin olduğu ve konunun etnik / 1rk kimliğiyle ilgili olduğu bir bağlamda, katılımcıların hissettikleri duyguya değil, mesajın geçerliliğini değerlendirmeye odaklanmalarıyla ilişkilendirmiştir. Araştırmacılara göre, böyle bir koşulda katılımcılar, kolektif suçluluk hissetmek yerine, mesajı verenin 1rk / etnik kimliğine odaklanarak mesaj kaynağının konuyla ilgili uzmanlığına, ne derece öznel davrandığına yönelik değerlendirme yapmaya çalışacaklardır. Bu açıklama mesajla ilgili hem kaynak hem odağı manipüle ettiğimiz Türk-Kürt çatışmasıyla ilişkilenen Sur'un kamulaştırılması bağlamında, duyguların değil, mesaja ilişkin veriler doğrultusunda değerlendirme yapmak üzere bilişsel bir sürecin aktif hale geldiği şeklinde yorumlanabilir. Ancak, bu yorum dolaylı bir yorumdur ve konuyla ilgili sınırlı sayıda çalışma olması nedeniyle, mesaj kaynağı ve odağının, ayrı ayrı ve birlikte manipüle edildiği koşullarda katılımcıların duygusal ve bilişsel süreçlerinin ileride yürütülecek çalışmalarda incelenmesi gerekmektedir.

Kolektif suçluluk, faillerin özür dileme ve zararı telafi edici davranışlarıyla (Sakallı-Uğurlu ve Soylu, 2016; Wohl ve ark., 2006) ilişkili olduğu için gruplar-arası çatışma çözümünde rol oynayabilecek önemli bir duygudur. Şimdiye kadar yürütülen, mesaj kaynağını ve mesaj odağını birbirinden bağımsız olarak inceleyen çalışmalar, iç grup (Doosje ve ark., 2006) ve avantajlı grup (Petty ve ark., 2001) üyelerinin mesajlarının ve üçüncü bir ağızdan verilen avantajlı grup / fail odaklı (Imhoff ve ark., 2012; Powell ve ark., 2005) mesajların daha yüksek düzeyde kolektif suçluluk hissedilmesine neden olduğunu göstermiştir. Ancak yürüttüğümüz bu çalışma, mesaj kaynağı ve odağıyla ilgili bilginin birlikte verilmesinin kolektif suçluluk duygusunu artırmada etkili olmayaca- 
ğını göstermiştir. Dolayısıyla, avantajlı grup üyelerinin kolektif suçluluk duygusu üzerinden, dezavantajlı grup üyelerinin zararını telafi edecek davranışlar göstermesine yönelik yürütülecek çalışma / müdahale programlarında, mesaj kaynağı ve mesaj odağıyla ilgili bilgileri birlikte vermek yerine sadece mesajın kaynağı ya da mesajın odağının manipüle edilmesinin daha doğru bir strateji olacağı görülmektedir.

Kontrol değişkenleriyle ilgili bulgulara baktığımızda ise, Türk kimliğiyle özdeşleşmenin ve olaya ilişkin meşruiyet algısının kolektif suçluluğu tahmin edebildiğini gördük. Sur'daki kamulaştırma sürecine odaklanan bu çalışmamızda Doosje ve ark. (1998) ile tutarlı olarak Türk kimliğiyle özdeşleşme düzeyi arttıkça katılımcıların Sur'un kamulaştırılması ve Kürtlerin mağduriyetiyle ilgili daha düşük düzeyde kolektif suçluluk hissettikleri sonucunu elde ettik. Olayın meşruiyetine yönelik alg1 değişkeninin etkisine baktığımızda ise, literatürde farklı çalışmaların ortaya koyduğu gibi (örn., Bahns ve Branscombe, 2011) Sur'un kamulaştırılmasının meşru olduğunu düşünenlerin daha düşük düzeyde kolektif suçluluk hissettikleri sonucuna ulaştık.

Alıcıya ait özellikler olarak değerlendirdiğimiz iç-grupla özdeşleşme ve meşruiyet algısının kolektif suçlulukla anlamlı ilişkisini düşündüğümüzde, özellikle meşruiyet algısı değișkeninin manipülasyonunun müdahale çalışmalarında kullanılabileceği düşünülebilir. $\mathrm{Bu}$ doğrultuda, avantajlı grup üyelerinin kolektif suçluluk duygusu üzerinden dezavantajlı grup üyelerinin zararını azaltacak politikalara destek vermeleri, zararı telafi edici davranışlar göstermeleri için, dezavantajlı grubun mağduriyetinin gayri meşruluğuna vurgu yapan mesajların verilmesi önerilebilir.

\section{Genel Değerlendirme}

Mesajın kaynağı ve odağını manipüle ettiğimiz koşulların temel etkisine baktığımızda mağdurun mağdur odaklı anlatımının, failin fail odaklı anlatımına kıyasla daha doğru / yansız algılandığını gördük. Elde edilen bulgu, katılımcıların failin yaptığı açıklamayı grubun çıkarlarına ters düşerek sorumluluk almasıyla ya da süreçten bireysel ya da grubu adına çıkar sağlamak istemesiyle ilişkilendirmeleriyle ilgili olabilir. Ancak, yapılan çalışmaların sayısının azlığı da göz önünde bulundurulduğunda, bulguların daha sağlıklı yorumlanması için mesaj kaynağının motivasyonuna ilişkin katılımcıların yapmış oldukları atıflara ilişkin gelecekte yürütülecek çalışmalara ihtiyaç vardır.

Çalışmanın kolektif suçlulukla ilgili bulgularına baktığımızda ise, gruplar-arası çatışmaların çözümünde motivasyon kaynağı olarak görülen kolektif suçluluk duygusunun ortaya çıkması için mesajın kaynağı ve oda- ğının birlikte manipüle edilmemesi gerektiği Litteford ve Jones'un (2017) çalışmasını da doğrulayacak şekilde ortaya konmuştur. Litteford ve Jones (2017) mesajın kaynağı ve odağının birlikte manipüle edildiği koşullarda alıcının mesaj kaynağına odaklanarak verilen mesajın geçerliliğine yönelik değerlendirme yaptığı; kendi duygusuna odaklanmadığı için kolektif suçluluk hissetmediği önerisini ortaya atmıştır. Elde ettiğimiz bulgular, mesaj kaynağı ve odağından sadece birinin manipüle edildiği koşullardaki bilişsel süreçlerle hem mesaj kaynağı hem de mesaj odağının birlikte manipüle edildiği koşullardaki bilişsel ve duygusal süreçlerin farklılığının gelecekte yürütülecek çalışmalar kapsamında incelenmesinin önemine işaret etmektedir.

Türk kimliğiyle özdeşleşme düzeyi yüksek ve Sur'un kamulaştırılmasını meşru gören katılımcıların bölge halkından biri tarafından verildiği söylenen mesajı daha yanlı algılaması da politik ve çatışma çözümüne yönelik uygulamalar açısından dikkate değer bir bulgudur. Elde edilen bulgu, mesaj kaynağı ve alıcının özellikleri dikkate alınarak, mesajın güvenilirliğinin artırılabileceğine, alıcının mesaj kaynağını güvenilir alg1lamayacağı durumların önceden tespit edilerek önlemler alınabileceğine işaret etmektedir.

Meşruiyet algısı ve Türk kimliği ile özdeşleşme değişkenlerinin hem düşük kolektif suçlulukla ilişsilenmesi hem de bu değişkenlerde yüksek puan alan katılımcıların mağdurdan gelen mesajları daha yanlı değerlendirmesi, bir grubun zarar gördüğü bir olay söz konusu olduğunda, avantajlı grup üyelerinde mağdur olan grubun zararını azaltmak ve telafi etmek adına bir motivasyon yaratmak istiyorsak, avantajlı grup üyelerinin iç-grupla özdeşleşmelerini artıracak ve bu üyelerin yaşanan mağduriyeti meşrulaştırmalarına neden olacak ifadelerden / mesajlardan kaçınmamız gerektiğini göstermektedir.

Gelecekteki çalışmalar için araştırmamızın sınırlilıklarından bahsetmek bu noktada faydalı olacaktır. Çalışmanın önemli sınırlılıklarından biri verinin yüksek oranda öğrenci örneklemine dayanmasıdır. Farklı sosyal medya hesaplarından çalışmanın duyurusu yapılmıştır ancak bu yolla çok az sayıda katılımcıya ulaşılabilmiştir. Çalışma konusunun politik olması ve verinin internet üzerinden toplanıyor olması nedeniyle katılımcıların verilerinin güvenliği konusunda endişe duyarak çalışmaya katılmak konusunda isteksizlik yaşamış olabileceği görüşündeyiz. Ayrıca, katılımcıların özellikle kolektif suçluluk ölçeğindeki maddeleri boş bırakmaları da konuya ilişkin hassasiyetin varlığına dair bir gösterge olarak düşünülebilir. Aynı bulguların, daha heterojen bir gruptan elde edilecek veri ile test edilmesi bu noktada önem taşımaktadır. Ayrıca, katılımcıların çalışmaya katılmadan önce Sur'daki gelişmelerden ne ölçüde haberdar oldukları ve Sur'daki kamulaştırmayı ne derece meşru 
algıladıkları değerlendirilmemiştir. İleride yürütülecek çalışmalarda, mesaj kaynağı ve odağıyla ilgili yapılan manipülasyonlardan önce bu değişkenlerle ilgili bilgi alınarak, değişkenlerin etkisinin kontrol edilmesi konuyla ilgili daha kapsamlı bilgi sağlayacaktır.

Güncel bir olayı ele alarak; mesajın kaynağı, odağ1 ve alıcının özelliklerini aynı anda değerlendirdiğimiz bu çalışmanın, hem kolektif suçluluk hem de mesajın değerlendirilmesiyle ilgili literatüre katkı sunması ve gruplar-arası çatışma çözümü için geliştirilecek müdahale programları için yol gösterici olması beklenmektedir.

\section{Kaynaklar}

Bahns, A. J. ve Branscombe, N. R. (2011). Effects of legitimizing discrimination against homosexuals on gay bashing. European Journal of Social Psychology, 41(3), 388-396. doi:10.1002/ejsp.784

Baysal (2018, 25 Mayıs). Nurcan Baysal'dan Sur kronolojisi. Bianet. https://m.bianet.org/bianet/yasam/197542-nurcan-baysal-dan-sur-kronolojisi

Bohner, G. (2001). Writing about rape: Use of the passive voice and other distancing text features as an expression of perceived responsibility of the victim. British Journal of Social Psychology, 40(4), 515-529. doi:10.1348/014466601164957

Bohner, G., Siebler, F., González, R., Haye, A. ve Schmidt, E. A. (2008). Situational flexibility of in-group-related attitudes: A single category IAT study of people with dual national identity. Group Processes \& Intergroup Relations, 11(3), 301-317. doi:10.1177/1368430208090644

Branscombe, N. R., Doosje, B. ve McGarty, C. (2002). Antecedents and consequences of collective guilt. D. M. Mackie ve E. R. Smith (Ed.), From prejudice to intergroup emotions: Differentiated reactions to social groups içinde (s. 49-66). Philadelphia: Psychology Press.

Çelebi, E., Verkuyten, M. ve Smyrnioti, N. (2016). Support for Kurdish language rights in Turkey: The roles of ethnic group, group identifications, contact, and intergroup perceptions. Ethnic and Racial Studies, 39(6), 1034-1051. doi:10.1080/01419870 .2015 .1103881

Çoymak, A. (2018). Kimmiş o ayrılıkçı: Türkiye'de uzun süredir devam eden Türk-Kürt çatışmasının çoklu sosyal kimlik dinamiklerini çözümlemek. Türk Psikoloji Yazıları, 21(Özel Say1), 38-61.

Çoymak, A. (yayında). At the heart of the intractable intergroup conflict: The psychology of privileged and disadvantaged identities in a nation-state. Kurdish Studies.

Çoymak, A. (2020). Functions of social representations in honour violence: The "Other East" as responsible. Social Justice Research, 33, 284-307. doi:10.1007/s11211-020-00349-6

Doosje, B., Branscombe, N. R., Spears, R. ve Manstead, A. S. R. (1998). Guilty by association: When one's group has a negative history. Journal of Personality and Social Psychology, 75(4), 872-886. doi:10.1037/0022-3514.75.4.872

Doosje, B., Branscombe, N. R., Spears, R. ve Manstead, A. S. R. (2006). Antecedents and consequences of group-based guilt: The effects of ingroup identification. Group Processes \& Intergroup Relations, 9(3), 325-338. doi:10.1177/1368430206064637 
Ekinci, B. (2016, 27 Mart). Sur'da kamulaştırmaya tepki: Evlerimizi alıyorlar, yargıya gideceğiz. https://www. bbc.com/turkce/haberler/2016/03/160327_sur_kamulastirma

Feldman, R. H. (1984). The influence of communicator characteristics on the nutrition attitudes and behavior of high school students. Journal of School Health, 54(4), 149-151. doi:10.1111/j.1746-1561.1984.tb08798.x

Ferguson, M. A. ve Branscombe. N. R. (2010). Collective guilt mediates the effect of beliefs about global warming on willingness to engage in mitigation behavior. Journal of Environmental Psychology, 30(2), 135-142. doi:10.1016/j.jenvp.2009.11.010

Gulker, J. E., Mark, A. Y. ve Monteith, M. J. (2013). Confronting prejudice: The who, what, and why of confrontation effectiveness. Social Influence, 8(4), 280-293. doi:10.1080/15534510.2012.736879

Henley, N. M., Miller, M. ve Beazley, J. A. (1995). Syntax, semantics, and sexual violence: Agency and the passive voice. Journal of Language and Social Psychology, 14(1-2), 60-84. doi: $10.1177 / 0261927 X 95141004$

Harth, N. S., Kessler, T. ve Leach, C. W. (2008). Advantaged group's emotional reactions to intergroup inequality: The dynamics of pride, guilt, and sympathy. Personality and Social Psychology Bulletin, 34(1), 115-129. doi:10.1177/0146167207309193

Herek, G. M., Gillis, J. R., Glunt, E. K., Lewis, J., Welton, D. ve Capitanio, J. (1998). Culturally sensitive AIDS educational videos for African American audiences. American Journal of Community Psychology, 26(5), 705-743. doi:10.1023/A:1022157914906.

Hovland, C. I., Janis, I. L. ve Kelley, H. H. (1953). Communication and persuasion; psychological studies of opinion change. New Haven, CT: Yale University Press.

Hovland, C. I. (1954). The effects of the mass media of communication. G. Lindzey, (Ed.), Handbook of social psychology (Vol. 2) içinde (s. 1061-1103). Cambridge, Mass.: Addison-Wesley.

Imhoff, R., Bilewicz, M. ve Erb, H. (2012). Collective regret versus collective guilt: Different emotional reactions to historical atrocities. European Journal of Social PSychology, 42(6), 729-742. doi:10.1002/ejsp.1886

Iyer, A., Leach, C. W. ve Crosby, F. J. (2003). White guilt and racial compensation: The benefits and limits of self focus. Personality and Social Psychology Bulletin, 29(1), 117-129. doi:10.1177/0146167202238377

Kamer, H. (2017, 10 Haziran). Sur'da inşa edilen Diyarbakır evleri tartışma yarattı. https://www.bbc.com/ turkce/haberler-dunya-40224152
Karaaslan, M. (2018). Diyarbakır Suriçi bölgesinin yeniden inşası ve hukuksal boyutu. Dicle Üniversitesi Hukuk Fakültesi Dergisi, 23(39), 335-373.

Klein, O., Licata, L. ve Pierucci, S. (2011). Does group identification facilitate or prevent collective guilt about past misdeeds? Resolving the paradox. British Journal of Social Psychology, 50(3), 563-572. doi:10.1111/j.2044-8309.2011.02028.x

Littleford, L. N. ve Jones, J. A. (2017). Framing and source effects on White college students' reactions to racial inequity information. Cultural Diversity and Ethnic Minority Psychology, 23(1), 143-153. doi:10.1037/cdp0000102

Lowery, B. S., Chow, R. M., Knowles, E. D. ve Unzueta, M. M. (2012). Paying for positive group esteem: How inequity frames affect Whites' responses to redistributive policies. Journal of Personality and Social Psychology, 102(2), 323-336. doi:10.1037/ a0024598

Lowery, B. S., Knowles, E. D. ve Unzueta, M. M. (2007). Framing inequity safely: Whites' motivated perceptions of racial privilege. Personality and Social Psychology Bulletin, 33(9), 1237-1250. doi:10.1177/0146167207303016

Mackie, D. M., Gastardo-Conaco, M. C. ve Skelly, J. J. (1992). Knowledge of the advocated position and the processing of ingroup and outgroup persuasive messages. Personality and Social Psychology Bulletin, 18(2), 145-151. doi: $10.1177 / 0146167292182005$

Miron, A. M., Branscombe, N. R. ve Biernat, M. (2010). Motivated shifting of justice standards. Personality and Social Psychology Bulletin, 36(6), 768-779. doi:10.1177/0146167210370031

Miron, A. M., Branscombe, N. R. ve Schmitt, M. T. (2006). Collective guilt as distress over illegitimate intergroup inequality. Group Processes \& Intergroup Relations, 9(2), 163-180. doi:10.1177/1368430206062075

Office of the United Nations the High Commissioner for Human Rights [OHCHR] (2017). Report on the human rights situation in South-East. https://www. ohchr.org/documents/countries/tr/ohchr_south-east_turkeyreport_10march2017.pdf

Özkan, O. S. (2014). The relationship between collective guilt and two modes of group identification: Ingroup glorification and ingroup attachment (Yayınlanmamış yüksek lisans tezi). Orta Doğu Teknik Üniversitesi, Ankara.

Öztürk, D. C. (2013). Socio-spatial practices of the pro-Kurdish municipalities: The case of Diyarbakır (Yayınlanmamış yüksek lisans tezi). Orta Doğu Teknik Üniversitesi, Ankara. 
Paköz, M. Z. ve Gün, A. (2016). The transformation and reorganization of cities in Southeastern Turkey: An examination from the safety perspective. $52^{\text {nd }}$ ISOCARP Congress, Durban, Güney Afrika.

Penelope, J. (1990). Speaking freely. New York: Pergamon.

Petty, R. E., Fleming, M. A., Priester, J. R. ve Feinstein, A. H. (2001). Individual versus group interest violation: Surprise as a determinant of argument scrutiny and persuasion. Social Cognition, 19(4), 418-442. doi:10.1521/soco.19.4.418.20758

Platow, M. ve Brodie, M. (1999). The effects of linguistic voice on evaluations and attributions of ingroup and outgroup members. Asian Journal of Social Psychology 2(2), 187-200. doi:10.1111/1467-839X.00033

Powell, A. A., Branscombe, N. R. ve Schmitt, M. T. (2005). Inequality as ingroup privilege or outgroup disadvantage: The impact of group focus on collective guilt and interracial attitudes. Personality and Social Psychology Bulletin, 31(4), 508-521. doi:10.1177/0146167204271713

Priester, J. R. ve Petty, R. E. (1995). Source attributions and persuasion: Perceived honesty as a determinant of message scrutiny. Personality and Social Psychology Bulletin, 21(6), 637-654. doi:10.1177/0146167295216010

Rasinski, H. M. ve Czopp, A. M. (2010). The effect of target status on witnesses' reactions to confrontations of bias. Basic and Applied Social Psychology, 32(1), 8-16. doi:10.1080/01973530903539754

Sakall1-Uğurlu, N. ve Soylu, B. (2016). Kolektif suçluluk: Öncülleri, çıktıları ve kaçınma yolları. Nesne Psikoloji Dergisi, 4(7), 59-87. doi:10.7816/nesne-04-07-04

Sharvit, K., Brambilla, M., Babush, M. ve Colucci, F. P. (2015). To feel or not to feel when my group harms others? The regulation of collective guilt as motivated reasoning. Personality and Social Psychology Bulletin, 41(9), 1223-1235. doi:10.1177/0146167215592843

Sherif, M. ve Hovland, C. I. (1961). Social judgment: Assimilation and contrast effects in communication and attitude change. Oxford, England: Yale University Press.

Solak, N., Tagar, M. R., Cohen-Chen, S., Saguy T. ve Halperin, E. (2017). Disappointment expression evokes collective guilt and collective action in intergroup conflict: The moderating role of legitimacy perceptions. Cognition and Emotion, 31(6), 1112-1126. doi:10.1080/02699931.2016.1197098

Sur'daki yıkımlara karşı platform kuruldu (2017, 20 May1s). Gazete Duvar. https://www.gazeteduvar. com.tr/gundem/2017/05/29/surdaki-yikimlara-karsi-platform-kuruldu/
Tajfel, H. ve Turner, J. C. (1986). The social identity theory of inter-group behavior. S. Worchel ve L. W. Austin (Ed.), Psychology of Intergroup Relations içinde (s. 7-24). Chicago: Nelson-Hall.

Uluğ, Ö. M. ve Cohrs, J. C. (2016). An exploration of lay people's Kurdish conflict frames in Turkey. Peace and Conflict: Journal of Peace Psychology, 22(2), 109-119. doi:10.1037/pac0000165

Uluğ, Ö. M. ve Cohrs, J. C. (2017). How do experts differ from politicians in understanding a conflict? A comparison of Track I and Track II actors. Conflict Resolution Quarterly, 35(2), 147-172. doi:10.1002/ crq. 21208

Wohl, M. J. A., Branscombe, N. R. ve Klar, Y. (2006). Collective guilt: Emotional reactions when one's group has done wrong or been wronged. European Review of Social Psychology, 17(1), 1-37. doi:10.1080/10463280600574815 


\section{Gönüllü Katılım ve Bilgilendirme Formu}

Sayın kat1limc1,

$\mathrm{Bu}$ araştırma [kör değerlendirme için kurum ismi silinmiştir] [kör değerlendirme için araştırmacı isimleri silinmiştir] proje çalışmasıdır. Bu proje kapsamında Sur'daki kamulaştırma süreci gruplar arası ilişkiler açısından değerlendirilecektir. Çalışmaya kendini Türk olarak tanımlayan kişilerin katılması beklenmektedir. Lütfen ankette verilen bilgiler çerçevesinde size en uygun olan cevabı işaretleyiniz. Ankette yer alan soruların doğru veya yanlış bir cevabı yoktur, önemli olan sizin düşüncelerinizdir. Sizden kimliğinizle ilgili hiçbir bilgi istenmemektedir. Vereceğiniz bilgiler tamamıyla gizli tutulacak, grup düzeyinde analiz edilecek ve çalışmadan elde edilecek sonuçlar sadece bilimsel amaçlı kullanılacaktır. Deneye katılım tamamen gönüllülük esasına dayanmaktadır. Çalışma yaklaşık 10 dakika sürecektir. Katılım sırasında sorulardan ya da herhangi başka bir nedenden dolayı kendinizi rahatsız hissederseniz deneyi yarıda bırakabilirsiniz, bu durumda cevaplarınız kullanılmayacaktır. Veri toplama ve analiz sürecinin sonunda elde edilen bulgularla ilgili tüm sorularınız cevaplandırılacaktır. Yardımlarınız ve katılımınız için teşekkür ederiz.

Bu çalışmaya tamamen gönüllü olarak katılıyorum ve istediğim zaman yarıda kesip çıkabileceğimi biliyorum. Verdiğim bilgilerin bilimsel amaçlı yayımlarda kullanılmasını kabul ediyorum.

\section{Fail perspektifinden ve fail odaklı}

Kamulaştırma, kamu yararı gerektiğinde, karşılığını peşin ödemek koşuluyla taşınmazların (ev, tarla vb. taşınamayan mülk) sahiplerinden izin alınmaksızın yasal yollarla tamamını veya bir kısmını almak, devletleştirmek demektir. Sur'daki evlerin kamulaştırmasüreci devam etmektedir. Aşağıda, Sur'daki kamulaştırma süreciyle ilgili 10 Haziran 2017 'de kamulaștırma sürecinden sorumlu kișilerden birivle yapılan mülakattan bir kısım verilmiştir. Bu aşamada, sizden istenen bu mülakatı okumanızdır.

Sur'un dört mahallesinde devam ettirdiğimiz sokağa çıkma yasağı üçüncü yılına girdi. Altı mahallede 2 Aralık 2015 tarihinde ilan ettiğimiz yasağı Hasırlı, Cemal Yılmaz, Savaş ve Fatihpaşa Mahallelerinde devam ettiriyoruz. 21 Mart 2016 'da Bakanlar Kurulu kararı ile riskli alan sınırları içerisinde bulunduğunu belirttiğimiz Sur ilçesinin 15 mahallesini hızlı bir şekilde kamulaştırma kararı ile kamulaştırdık.

11 Temmuz 2017'de uydu görüntülerinden alınan bilgilere göre altı mahallede 75.3 hektarlık alanın 46.3 hektarlık bölümünü yıktık. Rapora göre Cevapaşa, Savaş, Hasırlı, Cemal Yılmaz, Fatihpaşa ve Dabanoğlu Mahalllerinde toplamda 3 bin 569 yapıy1 y1ktık.

Kentsel dönüşüm kararı ile bir bölümünü daha önceki yıllarda yıktığımız Alipaşa ve Lalabey mahallelerindeki evlerin kalan kısmını da bu karar doğrultusunda boşaltıp yıkıyoruz. Her iki mahallede 1012 hak sahibinin evini yıkacağız. Alipaşa ve Lalabey Mahallelerinin bir bölümünde 23 Mayıs'ta yıkıma başladık. Evlerini kamuşaltırdığımız hak sahipleri Sur'dan çıkmak istemediklerini söylüyorlar. Ancak o tarihten beri yıkım kapsamındaki evlerin çoğunda su ve elektriği kestik. Ev sahiplerine altı ay kira yardımı ve nakliye ücretini karşılama sözü verdik ama mahalle sakinleri bunun geçici bir çözüm olduğunu söyleyerek evlerinden çıkmayacaklarını tekrarlıyorlar. 


\section{Mağdur perspektifinden ve fail odaklı}

Kamulaştırma, kamu yararı gerektiğinde, karşılığını peşin ödemek koşuluyla taşınmazların (ev, tarla vb. taşınamayan mülk) sahiplerinden izin alınmaksızın yasal yollarla tamamını veya bir kısmını almak, devletleştirmek demektir. Sur'daki evlerin kamulaştırma süreci devam etmektedir. Aşağıda, Sur' daki kamulaştırma süreciyle ilgili 10 Haziran 2017 'de bölge halkından bir kișiyle yapılan mülakattan bir kısım verilmiştir. Bu aşamada, sizden istenen bu mülakatı okumanızdır. Sur'daki dört mahallemizde devam ettirdikleri sokağa çıkma yasağı üçüncü yılına girdi. Altı mahallede 2 Aralık 2015 tarihinde ilan ettikleri yasağı Hasırlı, Cemal Yılmaz, Savaş ve Fatihpaşa Mahallelerimizde devam ettiriyorlar. 21 Mart 2016'da Bakanlar Kurulu'nun verdiği karar ile riskli alan sınırları içerisinde bulunduğunu belirttikleri Sur ilçemizdeki 15 mahallemizi hızlı bir şekilde kamulaştırma kararı ile kamulaştırdılar.

11 Temmuz 2017'de uydu görüntülerinden alınan bilgilere göre altı mahallemizdeki 75.3 hektarlık alanın 46.3 hektarlık bölümünü yıktılar. Rapora göre Cevapaşa, Savaş, Hasırlı, Cemal Yılmaz, Fatihpaşa ve Dabanoğlu Mahalllerimizdeki toplamda 3 bin 569 yapıyı yıktılar.

Kentsel dönüşüm kararı ile bir bölümünü daha önceki yıllarda yıktıkları Alipaşa ve Lalabey mahallelerimizdeki evlerin kalan kısmını da bu kararı gerekçe göstererek boşaltıp yıkıyorlar. Her iki mahallemizde 1012 hak sahibinin evini yıkacaklar. Alipaşa ve Lalabey Mahallelerimizin bir bölümünde 23 Mayıs’ta yıkımı başlattılar. Evleri kamulaştırılan hak sahipleri olarak Sur'dan çıkmak istemediğimizi söylüyoruz. Ancak o tarihten beri yıkım kapsamındaki evlerin çoğunda su ve elektriği kestiler. Ev sahiplerine altı ay kira yardımı ve nakliye ücretini karşılama sözü verdiler ama mahalle sakinleri olarak bunun geçici bir çözüm olduğunu söyleyerek evlerimizden çıkmayacağımızı tekrarlıyoruz.

\section{Fail perspektifinden ve mağdur odaklı}

Kamulaştırma, kamu yararı gerektiğinde, karşılığını peşin ödemek koşuluyla taşınmazların (ev, tarla vb. taşınamayan mülk) sahiplerinden izin alınmaksızın yasal yollarla tamamını veya bir kısmını almak, devletleştirmek demektir. Sur'daki evlerin kamulaştırma süreci devam etmektedir. Aşağıda, Sur'daki kamulaştırma süreciyle ilgili 10 Haziran 2017 'de kamulaștırma sürecinden sorumlu kișilerden birivle yapılan mülakattan bir kısım verilmiştir. Bu aşamada, sizden istenen bu mülakatı okumanızdır.

Sur' un dört mahallesinde devam eden sokağa çıkma yasağı üçüncü yılına girdi. Altı mahallede 2 Aralık 2015 tarihinde ilan edilen yasak Hasırlı, Cemal Yılmaz, Savaş ve Fatihpaşa Mahallelerinde devam ediyor. 21 Mart 2016'da Bakanlar Kurulu kararı ile riskli alan sınırları içerisinde bulunduğu belirtilen Sur ilçesinin 15 mahallesi hızlı bir şekilde kamulaştırma kararı ile kamulaştırıldı.

11 Temmuz 2017'de uydu görüntülerinden alınan bilgilere göre altı mahallenin 75.3 hektarlık alanın 46.3 hektarlık bölümü yıkıld1. Rapora göre Cevapaşa, Savaş, Hasırlı, Cemal Yılmaz, Fatihpaşa ve Dabanoğlu Mahallerinde toplamda 3 bin 569 yapı yıkıldı. Kentsel dönüşüm kararı ile bir bölümü daha önceki yıllarda yıkılan Alipaşa ve Lalabey mahallelerindeki evlerin kalan kısmı da bu karar doğrultusunda boşaltılıp yıkılıyor. Her iki mahallede 1012 hak sahibinin evi yıkılacak. Alipaşa ve Lalabey Mahallelerinin bir bölümünde 23 Mayıs’ta yıkım başladı. Evleri kamulaştırılan hak sahipleri Sur' dan çıkmak istemediklerini söylüyorlar. Ancak o tarihten beri yıkım kapsamındaki evlerin çoğunda su ve elektrikler kesildi. Ev sahiplerine altı ay kira yardımı ve nakliye ücretini karşılama sözü verildi ama mahalle sakinleri bunun geçici bir çözüm olduğunu söyleyerek evlerinden çıkmayacaklarını tekrarlıyorlar. 


\section{Mağdur perspektifinden ve mağdur odaklı}

Kamulaştırma, kamu yararı gerektiğinde, karşılığını peşin ödemek koşuluyla taşınmazların (ev, tarla vb. taşınamayan mülk) sahiplerinden izin alınmaksızın yasal yollarla tamamını veya bir kısmını almak, devletleştirmek demektir. Sur' daki evlerin kamulaştırma süreci devam etmektedir. Aşağıda, Sur'daki kamulaştırma süreciyle ilgili 10 Haziran 2017 'de bölge halkından bir kișiyle yapılan mülakattan bir kısım verilmiştir. Bu aşamada, sizden istenen bu mülakatı okumanızdır.

Sur'daki dört mahallemizde devam ettirilen sokağa çıkma yasağı üçüncü yılına girdi. Altı mahallemizde 2 Aralık 2015 tarihinde ilan edilen yasak Hasırl1, Cemal Yılmaz, Savaş ve Fatihpaşa Mahallelerimizde devam ettiriliyor. 21 Mart 2016 'da Bakanlar Kurulu kararı ile riskli alan sınırları içerisinde bulunduğu belirtilen Sur ilçemizin 15 mahallesi hızlı bir şekilde kamulaştırma kararı ile kamulaştırıldı.

11 Temmuz 2017'de uydu görüntülerinden alınan bilgilere göre altı mahallemizin 75.3 hektarlık alanın 46.3 hektarlık bölümü yıkıldı. Rapora göre Cevapaşa, Savaş, Hasırlı, Cemal Yılmaz, Fatihpaşa ve Dabanoğlu Mahalllerimizde toplamda 3 bin 569 yapı yıkıldı.. Kentsel dönüşüm kararı ile bir bölümü daha önceki yıllarda yıkılan Alipaşa ve Lalabey mahallelerindeki evlerimizin kalan kısmı da bu karar doğrultusunda boşaltılıp yıkılıyor. Her iki mahallemizde 1012 hak sahibinin evi yıkılacak. Alipaşa ve Lalabey Mahallelerimizin bir bölümünde 23 Mayıs’ta yıkıma başlandı. Evleri kamulaştırılan hak sahipleri olarak Sur'dan çıkmak istemediğimizi söylüyoruz. Ancak o tarihten beri yıkım kapsamındaki evlerimizin çoğunda su ve elektrikler kesildi. Bize altı ay kira yardımı ve nakliye ücretini karşılama sözü verildi ama mahalle sakinleri olarak bunun geçici bir çözüm olduğunu söyleyerek evlerimizden çıkmayacağımızı tekrarlıyoruz. 


\section{Mesajın Değerlendirilmesi}

Şimdi sizden istenen bu haberle ve Sur'daki kamulaştırma süreciyle ilgili aşağıda verilen soruları cevaplamanızdır. Lütfen sorulara içinizden geldiği gibi, sizi en iyi yansıttığını düşündüğünüz şekilde cevap veriniz.

\begin{tabular}{|c|c|c|c|c|c|c|c|}
\hline & 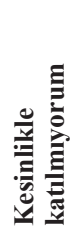 & 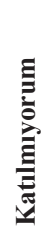 & 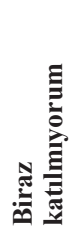 & 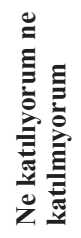 & 氞 & 离 & 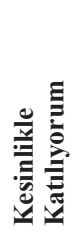 \\
\hline 1.Yapılan mülakatın doğru bilgiler içerdiğini düşünüyorum. & 1 & 2 & 3 & 4 & 5 & 6 & 7 \\
\hline $\begin{array}{l}\text { 2.Surdaki kamulaştırma süreciyle ilgili yapılan bu mülakatın } \\
\text { yanlı olduğunu düşünüyorum. }\end{array}$ & 1 & 2 & 3 & 4 & 5 & 6 & 7 \\
\hline $\begin{array}{l}\text { 3.Sur ilçesindeki mahallelerin kamulaştırılmasıyla ilgili sürecin } \\
\text { haklı ve adil olduğunu düşünüyorum. }\end{array}$ & 1 & 2 & 3 & 4 & 5 & 6 & 7 \\
\hline $\begin{array}{l}\text { 4.Surdaki evlerin kamulaştırılmasının var olan sorunu çözmek } \\
\text { için iyi bir yol olduğunu düşünüyorum. }\end{array}$ & 1 & 2 & 3 & 4 & 5 & 6 & 7 \\
\hline $\begin{array}{l}\text { 5.Surdaki evlerin kamulaştırılmasının var olan sorunu çözmeye } \\
\text { katkı sağlayacağını düşünüyorum. }\end{array}$ & 1 & 2 & 3 & 4 & 5 & 6 & 7 \\
\hline
\end{tabular}

